MT-DP - 2010/ 1

\title{
Agglomeration Premium and Trading Activity of Firms
}

GÁBOR BÉKÉS - PÉTER HARASZTOSI 
Discussion papers

MT-DP - 2010/1

Institute of Economics, Hungarian Academy of Sciences

KTI/IE Discussion Papers are circulated to promote discussion and provoque comments. Any references to discussion papers should clearly state that the paper is preliminary. Materials published in this series may subject to further publication.

Agglomeration Premium and Trading Activity of Firms

Author:

Gábor Békés

research fellow

Institute of Economics - Hungarian Academy of Sciences

E-mail: bekes@econ.core.hu

Péter Harasztosi

Phd Student

Central Europan University

harasztosi@gmail.com

January 2010

ISBN $978963 \quad 9796 \quad 881$

ISSN $1785377 \mathrm{X}$ 


\title{
Agglomeration Premium and Trading Activity of Firms
}

\author{
Gábor Békés - Péter Harasztosi
}

\begin{abstract}
Firms may benefit from proximity to each other due to the existence of several externalities. The productivity premia of firms located in agglomerated regions an be attributed to savings and gains from external economies. However, the capacity to absorb information may depend on activities of the firm, such as involvement in international trade. Importers, exporters and two-way traders are likely to employ a different bundle of resources and be organised differently so that they would appreciate inputs and information from other firms in a different fashion and intensity. Getting a better understanding of such external economies by looking at various types of firms is the focus of present paper. Using Hungarian manufacturing data from 1992-2003, we confirm that firms perform better in agglomerated areas and show that traders gain more in terms of productivity than non-traders when agglomeration rises. Firms that are stable participants of international trade gain $16 \%$ in terms of total factor productivity growth as agglomeration doubles while non-traders may not benefit from agglomeration at all. Results also suggest that traders' productivity premium is most apparent in urbanised economies.
\end{abstract}

JEL classification: F14, R12, R30

Keywords: agglomeration, international trade, firm heterogeneity

Acknowledgements

Corresponding author: Péter Harasztosi, Budapest 1112 Budaörsi út 45, harasztosi@gmail.com. We are grateful for comments by Balázs Muraközy, Miklós Koren, Gábor Kézdi and Gábor Kőrösi and seminar participants at Vienna, Edinburgh, IEHAS and CEU Budapest. This paper was produced in the framework of MICRO-DYN (www.micro-dyn.eu), an international research project funded by the EU Sixth Framework Programme (www.cordis.lu) with socio-economic sciences and humanities (http://ec.europa.eu/research/social-sciences/index_en.html). This publication reflects only the author's views, the European Community is not liable for any use that may be made of the information contained therein. 


\title{
Agglomerációs termelékenységi többlet és a külkereskedő vállalatok
}

\author{
Békés Gábor - Harasztosi Péter
}

\section{Összefoglaló}

\begin{abstract}
A tanulmány azokat a pozitív külső hatásokat vizsgálja, melyekből a vállalatok egymáshoz való földrajzi közelségük miatt részesülhetnek. Az agglomerációs környezetben múködő vállalatok termelékenységi többlete részben ezen előnyök kihasználásának tulajdonítható. A vállalatok azonban nem képesek azonos mértékben felhasználni az agglomeráció nyújtotta előnyöket. Egy külkereskedő vállalat egészen más termelési tényezőket, más információt igényel, illetve azokat más keretek között és más intenzitással hasznosítja, mint egy csak belföldi partnerekkel érintkező vállalat. A környezet agglomerációs jellegéből származó előnyöket a tanulmány a vállalatok különbözősége, külkereskedelemben való részvétele alapján közelíti meg. A tanulmány a magyar feldolgozóipari vállalatokat 1992-tôl 2003-ig tartalmazó panel adatbázis segítségével megmutatja, hogy a külkereskedő vállalatok az agglomeráció növekedésével arányosan termelékenyebbek. A nem külkereskedő vállalatok esetében mindez nem mutatható ki. A külkereskedelmi tevékenységben stabilan résztvevők 16 százalékkal termelékenyebbek egy kétszer sürübb környezetben, mint a nem kereskedő cégek.
\end{abstract}

JEL: F14, R12, R30

Tárgyszavak: agglomeráció, külkereskedelem, vállalati szintű heterogeneitás 


\section{Introduction}

It is a frequently observed feature of economic geography that firms appreciate proximity to each other. Manufacturing belts, industrial clusters, cities or science parks are all manifestations of this phenomenon. Sometimes, actual geography, hills, rivers and sea-berth or the amount of sunshine will determine firms' locations. However, centripetal forces of modern economies stemming from savings in transport costs, the collaboration of companies or various Marshallian externalities will result in such agglomerated areas.

Gains from being close to others yield economic benefits. Firms in more densely populated areas were found to be more productive (See Foster \& Stehrer (2008) and Combes et al. (2009)). While such a positive correlation between density and productivity might stem from natural advantages, the productivity premia of agglomerations can be attributed to savings and gains from external economies. Not all firms are expected to be able to enjoy such externalities, and the capacity to absorb information may depend on activities of the firm, such as involvement in international trade. Getting a better understanding of such external economies by looking at various types of firms is the focus of present paper.

These externalities were of course proposed by Marshall (1920), who identified input-sharing, labour-market pooling and localised technological spillovers as key factors when examining cutlery manufacturers in England. External economies and spillovers play an important role also in growth literature. Endogenous growth models following Lucas (1988) emphasise the role of knowledge spillovers between firms as promoters of technological change and engines of development. More recently in a survey Hanson (2000) identified three broader channels that make more agglomerated regions more productive: (i) proximity of other firms reduce transport cost and created increasing returns to firms with fixed costs of production as in Krugman (1991), (ii) externalities created by the density of the firms in the locality increase productivity, and (iii) dense economic activity allows for a greater degree of specialisation.

The basic picture about the higher productivity of agglomerations can be seized without firm level information through summary statistics, through regional level data. Using a cross section of US county level data Ciccone \& Hall (1996) tested whether labour density affected productivity. They find that doubling labour density increases labour productivity by $6 \%$ on average. Using sub-regional data for a set of European countries (NUTS3-level data for Germany, Italy, Spain, France and the UK), Ciccone (2002) repeated the exercise and found that doubling the density of labour results in an average increase of $5 \%$ in labour productivity. Dekle \& Eaton (1999) estimate the agglomeration effects would produce productivity growth in Japan only to find that agglomeration explains $5.6 \%$ labour productivity growth in manufacturing. More recently, Brülhart \& Mathys (2008) estimate the effect of labour density across European regions. Estimating the long run elasticity between density and productivity on a panel of 20 European countries at NUTS-2 level, 
they find it to be $13 \%$. They argue that the higher elasticity found in CEE countries can be partly attributed to the legacy of central planning concentrating industries near the capitals.

Despite the primarily microeconomic nature of agglomeration economies, previously mentioned studies investigate the effect of agglomeration economies using regional level aggregate data and handle it as a black-box. However, more recent studies imply, that external economies affect firm behaviour and performance differently depending on the characteristics of the firm and the extent of agglomeration.

On French firm level data Martin et al. (2008) have shown that agglomeration economies have significant though nonlinear effect. Firms are more productive in more dense environments only up-to a point, then productivity premia are diminished by the increasing congestion effects. They also found that firms especially benefit from the proximity of the firms in their own sector. Doubling the sector employment size around a firm increases productivity by $4 \%$ on average. Heterogenous response is underlined by Békés, Kleinert \& Toubal (2009), who show using Hungarian data that while the most productive firms gain substantially from spillovers, the worst quartile of firms loose out on higher presence of foreign firms.

In addition, on French data Combes et al. (2009) try to tell agglomeration and selection apart. The study concluded that the observed productivity premia across French metropolitan firms are not due to the selection of more productive firms but to agglomeration economies. They also show that agglomeration effects increase with the productivity of the firm. Though the firm-level empirical literature is only recently emerging, findings suggest that not all firms benefit from agglomeration economies to the same extent.

Investigating clustering of Danish firms, Strøjer Madsen et al. (2003) find significantly higher productivity across concentrated firms. However, wood and textile manufacturing showed higher sensitivity to clustering than other sectors.

Motivated by these results, the present paper intends to open up the blackbox of aggregation and to look more into the effects of firm level heterogeneity to the assessment of agglomeration economies. Given the prevalence of evidence suggesting how firms active in international trade operate differently from non-traders in terms of using inputs or capital as well as in terms of performance, the focus will be on the effect of agglomeration economies on international traders. Importers, exporters and two-way traders are likely to employ a different bundle of resources and be organised differently so that they would appreciate inputs and information from other firms in a different fashion and intensity.

Since Bernard \& Jensen (1999)'s seminal empirical paper on U.S. exporters, many have documented that trading activity is a rare and rather concentrated activity. Also, firms engaging in international trade, besides the fact that their products cross national borders, are different from non-trading firms in many 
aspects. These firms employ more and better skilled workers, pay higher wages and are more productive than firms selling within borders only. Many of these differences related to the operation of the firms were found and documented both for the U.S. and European countries, for example Bernard et al. (2007) or Mayer \& Ottaviano (2008).

While new economic geography and trade models (Krugman 1991, Ottaviano et al. 2002) explain the unequal spatial distribution of economic activity and international trade together, recent empirical literature on trading firms gives little guidance on the relationship between trading behaviour and agglomeration. We know, that international traders evaluate many location related factors differently. Indeed, traders are better off being in the proximity of firstgeography factors such as national borders or bodies of water. As shown by Koenig (2005), French overseas exporters tend to locate near those cities and ports that provide access to their respective partner countries. We know less about the so called second-geography factors: proximity of other firms and density of economic environment.

This paper focuses on the agglomeration-productivity relationship by looking at the productivity premia of firms and investigates if certain firms, those who are active in international trade, behave differently. In other words, our central questions are if internationalised firms showed different performance in more densely populated environments and whether one could see a difference in their agglomeration premia with respect to non trading firms.

The rest of the paper is organised as follows. In Section 2 we argue why international traders might benefit from agglomeration economies. Section 3 introduces the data and discusses basic spatial issues. Section 4 discusses empirical strategy and estimation methods. Section 5 estimates whether trading firms are more productive in more agglomerated environment. We find that trading firms show higher productivity in agglomerations, while no evidence of agglomeration economies are found across nontrading firms. Section 6 tries to identify the possible sources of the relatively higher productivity of traders in agglomeration by disentangling agglomeration into localisation and urbanisation and sees which correlates more with the productivity of trading firms. Results suggest, that larger part of the observed premium of traders is due to urbanisation economies.

\section{Mechanics of Agglomeration}

Agglomeration economies, as externalities to firms, are in fact sums of many individual externalities reinforcing each other. These are in most cases observationally equivalent, implying that its different channels are more likely to be distinguished theoretically than empirically. As Rosenthal \& Strange (2004) put it: "it can be shown that agglomeration economies whose sources are knowledge spillovers, labour market pooling, or input sharing all manifest themselves in pretty much the same way." (p. 2146) Though, we do not as- 
sess the contribution to agglomeration effects of these channels individually, this section provides a deeper insight into the agglomeration externalities and discusses what is special in international traders.

\subsection{Agglomeration forces}

Input sharing: In a dense economic surroundings, individual firms have abundant opportunities for both the local outsourcing of inputs and the distribution of output, thus reducing transportation costs. In the case of scale economies, upstream firms are able to procure their inputs more cheaply if they express demand in a more dense environment. That is, downstream firms in concentrated industry locations will be able to outsource their input needs, which creates a higher level of vertical disintegration. The love of input variety is not necessarily limited to one industry, but also applies to the interplay between many. This feature of increasing returns in intermediate inputs lies at the core of monopolistic competition models of economic geography and trade (see e.g. Ciccone \& Hall (1996), Abdel-Rahman (1988)).

Labour market externalities: In agglomerations firms have access to established pools of labour that are both specialised and deep, thus minimising costs associated with search and training. In more urban environment education tends to be of better quality and due to the larger number of people development of special skills is more possible. Urban areas not only provide better skilled and more specialised workers, but also allow for better on-the-job human capital accumulation as pointed out by Glaeser \& Mare (2001). This implies that firms will more likely find the employee of their needs and thus better employment matches are created. Additionally, if a larger pool of employees are available, firms do not have to keep up ineffective matches. As shown by Bleakley \& Lin (2007) workers have lower searching cost and lower tendency to leave their own sector in denser labour markets.

Knowledge spillovers: Concentration of firms is thought to enhance the production of knowledge and increase spillovers, via face-to-face exchange of tacit knowledge or through the mobility of human capital between firms. Knowledge spillovers are central element of innovation and R\&D activity and economic development. Marshall (1920) described fertility of spillovers in book IV, chapter X. $\S 3$. as: "if one man starts a new idea, it is taken up by others and combined with suggestions of their own; and thus it becomes the source of further new ideas." If knowledge is tacit knowledge spillovers might be subject to geographical boundaries. The propagation of tacit knowledge requires faceto-face communication and is hard to capture of codify. Audretsch \& Feldman (2004) and Jaffe et al. (1993) use patent citations as the result of knowledge spillovers to grasp the phenomenon. They find that R\&D activity is rather localised across the U.S. 


\subsection{What is special in trading firms?}

These agglomeration effects do not benefit all firms the same extent. Sensitivity to agglomeration economies depends on the scale of operation, the special skill and production-technique needs of the firms, and the degree to which the firm is part of a vertically disintegrated production process. We argue that international traders particulary benefit from the aforementioned channels.

Better factors of production: Competing internationally is a demanding task for domestic firms. Innovation in product quality and services is essential to survive the competition. Firms in a dense economic environment have a better chance to find matching, either domestic or foreign input to their production process, which makes the firm more productive and able to export its own products. Furthermore, dense economies and/or industrially specialised regions provide better matching labour force in terms of skills and higher quality of human capital, which increases firm performance. When explaining the relative small ratio of Colombian exporters, Brooks (2003) finds that insufficient level of product quality plays important role. More recently, Imbriani et al. (2008), investigating export propensity of Italian firms, find that product quality gives strict ordering to firms in trading activity.

Meeting Scale requirements: Entering an international market implies that higher than local or domestic demand concentrates in a firm or in a region. This is especially true in the case of Hungary, a small open economy, where exporters in most cases sell to larger than local markets. In order to be able to compete abroad the scale requirements are substantial. Agglomeration economies - via input sharing - are able to create sufficient backward linkages, such that other firms find it more profitable to supply. Additionally, local outsourcing of parts of the production process is more likely.

Knowledge to trade: The fixed cost of international trade is often referred to as that of marketing, repackaging, finding distribution channels. These cost depend on the information availability on the foreign market at the place of production. Knowledge spillovers on the techniques of trade in an agglomerated environment tend to reduce these cost. For example Lovely et al. (2005) investigate the location of exporting firm headquarters in the U.S. They find that firms that export to not easily accessible countries tend to locate in each others proximity. Also, trade related tacit knowledge is more likely to circulate better in dense environments. In a recent study on tacit export knowledge, Soon \& Fraser (2006) interviewing Australian exporters, find that information on overseas business opportunities and on variations in export customer preference is a valued and not easily accessible information for managers.

Export Spillovers: The idea of export spillovers are connected to the previous point. It asks whether the presence of other traders in the vicinity (mainly multinationals and FDI) affects extensive or intensive margin of trade of the local firms. Aitken et al. (1997) examine Mexican plants' export behaviour and find that propensity to trade is positively affected by the presence of multinational firms in the same location, but is not affected by general exporter 
presence. On Colombian, Mexican and Moroccan data Clerides et al. (1998) find evidence of positive regional externalities. Most trading manufacturers are multi-product firms and handle complex processes. For example, on average Hungarian manufacturers export 7 and import 20 different HS6 category products. This presupposes advanced management and learning skills, higher absorption capacity. That is international traders are more able to harness technology and knowledge spillovers. The empirical evidence on this between traders' spillovers are, however, mixed. For example Bernard \& Jensen (2004) find that for US exporters the spillovers from other exporting firms are negligible, while Kneller \& Pisu (2007) investigating export spillovers from FDI on UK data find that the presence of foreign multinationals in the same industry or region affect positively the intensive and extensive margins of trade.

Import Spillovers: Just as in the case of exporting activity, firms also might draw benefit from proximity of importers. Finding appropriate and reliable suppliers might be costly and local information spillovers can effectively lower fixed costs related to search. While there is growing evidence on the positive effect of imports on productivity see e.g. Halpern et al. (2009) or Acharya \& Keller (2008), to the authors knowledge local import spillovers have been so far neglected by the literature and evidence is limited.

\section{Data Description}

The empirical analysis uses a panel of Hungarian manufacturing firms from 1992-2003 with very detailed firm level information on balance sheet and trading activity. The panel contains on average 15000 firms yearly ${ }^{2}$ of the manufacturing sectors ranging from 17 to 37 of the EU's NACE 2 digit classification. For detailed description of the dataset see Békés, Muraközy \& Harasztosi (2009).

\subsection{Hungarian geography}

The balance sheet information provides the necessary variables to estimate productivity by value added or total factor productivity (TFP). It gives further information on firm size and whether the firm is owned by a foreign owner. The balance sheet data has been merged with customs information, thus, we see whether a given firm is engaged in exporting or importing activity in the given year. In this study we will refer to a firm being a trader in a given year if it is either exporting or importing.

The geography data point to the locations of the headquarters of the firms.

${ }^{2}$ From 2000 to 2003 the number of firms drops in our panel as very small firms are missing in that period. To correct for this sampling anomaly, we drop firms with less than 5 employees from all years of the data. 
Headquarters in the case of manufacturing coincides with the place of production with higher probability than in other sectors. The most disaggregated level of location identification at our disposal are zip-codes. Unfortunately, the Hungarian zipcode system is not a one-to-one mapping, therefore larger geographical entities are required. From larger to smaller these are: county (megye), micro-region (kistérség) and zipcode levels. ${ }^{3}$

Table 1

Summary of Hungarian administrative spatial zoning

\begin{tabular}{llll}
\hline \hline EU level units & Hungarian equivalent & number & avg. size $\mathrm{km}^{2}$ \\
\hline & & & \\
NUTS2 & EU administrative region & 7 & 13861 \\
NUTS3 & 19 counties, Budapest & 20 & 4651 \\
NUTS4 & micro regions & 150 & 620 \\
NUTS5 & municipalities & 3125 & 30 \\
\hline \hline
\end{tabular}

In Table 1 Hungarian spatial units are summarised in correspondence with the EU zoning. Hungary consists of 20 counties, which stratification includes the capital, Budapest as a separate entity and corresponds to the NUTS 3 level EU regional policy unit. There are 150 micro-regions, and a county holds eight micro-regions on average. Each micro-region contains approximately 410 towns and villages, which area corresponds to a range where firms are operating within a 20-30 km radius. Their average size is $620 \mathrm{~km}^{2}$ and 70 thousand inhabitants. ${ }^{4}$

\subsection{Regional density and productivity distribution}

In line with international findings, more densely populated regions are found to be more productive in Hungary, too. As an illustration ahead of refined analysis to come, let us highlight some key correlations between productivity and density. To get them, firm level employment and value added are aggregated up to (NUTS-4) micro-region level.

First, regions that have twice as many workers boost firms that are about 19 percent more productive on average. Figure 1 illustrates the productivity premium of the denser regions for the year $1999 .{ }^{5}$ The figure plots the density of

\footnotetext{
${ }^{3}$ While zipcode level is the most disaggregated information at hand we will not use them in this study for two reasons. First, there are many towns and cities that hold numerous zipcodes with considerable within-town variation over time. Second, there are zipcodes that correspond to two or more villages, small towns. Both hinder unique identification.

${ }^{4}$ The number of micro-regions was originally set to 150 by the Statistical Office, which was later modified to 168 and more recently to 173 . This study uses the 150 micro-region level stratification to assess agglomeration economies. See Table 11 for summary statistics of the micro-regions.

${ }^{5}$ In the Appendix we show the spatial distribution of the underlying variables on the maps of Hungary for 1999.
} 
Fig. 1. Productivity plotted against density in 1999

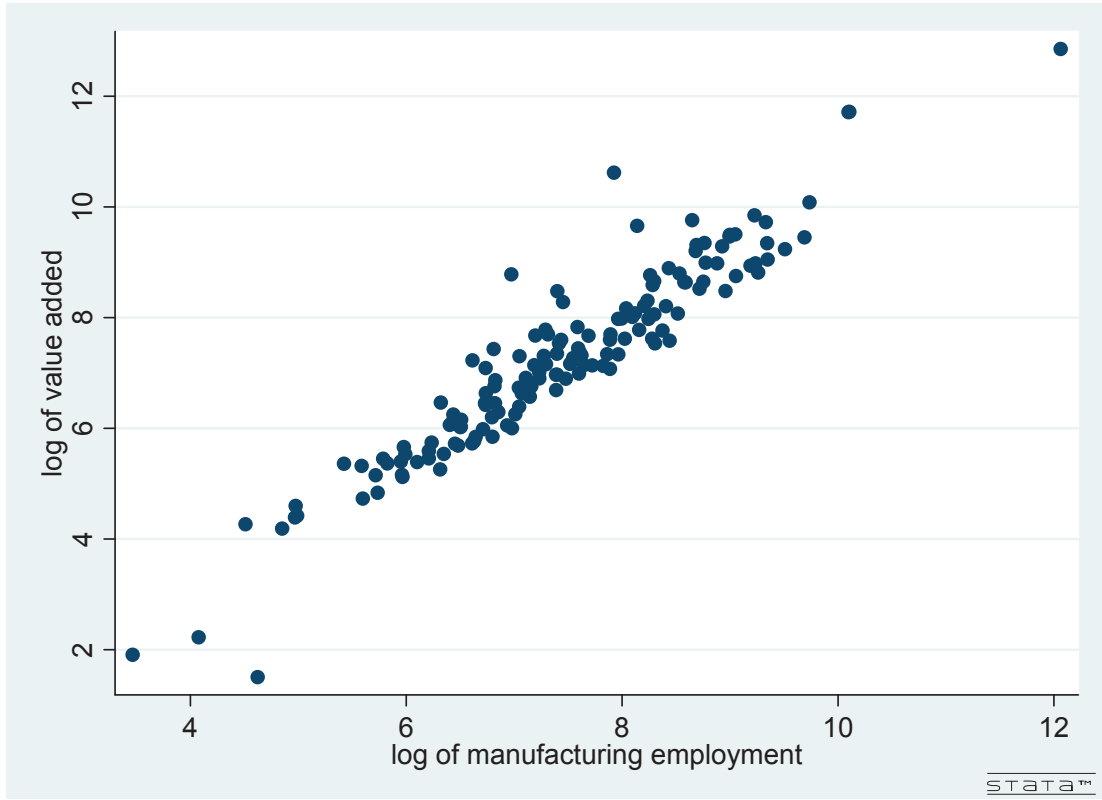

manufacturing employment in a microregion against the average log productivity calculated over the firms of the microregion. Density as the number of employees / area captures the average distance between firms and people that will translate into a measure of easiness to communicate. It shows that firms in twice as dense, or agglomerated (larger in terms of employment/area) areas show a X\% higher labour productivity. This finding bodes well in international evidence, and this paper aims at dissecting this effect - turning to the firm level.

The raw elasticity estimate obtained from regressing the log of average value added in a micro-region on the employment density is 19 percent. Compared to raw elasticities found for other countries (see. e.g Ciccone (2002) for EU countries and Combes et al. (2008) for France) the Hungarian figure is rather high. Brülhart \& Mathys (2008), who find that both raw elasticity and the casual effect of agglomeration on productivity is higher in CEEC countries, explain the phenomenon as the heritage from the concentrated central planning around the capital cities.

Second, we may observe the working of agglomeration economies at the extreme level of regional disaggregation: cities. Indeed, the essence of agglomeration is captured in cities. Cities provide indivisibilities, better skilled and more diversified labour force and a wider range of specialised services and suppliers that facilitate the emergence of agglomeration economies. To have a sketch of the relationship between agglomeration and productivity at firm level a simple exercise is conducted. A crude, binary measure of agglomeration is proposed. Hungarian firms are divided into two groups, to those in cities with on average more than 10.000 manufacturing workers and to those located elsewhere. This 
distinction identifies the 10 most populated Hungarian cities as agglomerated locations.

Figure 2, panel a) compares productivity distributions of agglomeration and non-agglomeration firms. The figure shows that the productivity distribution of agglomerated firm is more dilated and its mean is more towards the positive segment of the productivity range. This suggests, that firms in different productivity quantiles are affected differently by agglomeration economies and there are more high productivity firms found in cities. ${ }^{6}$

Fig. 2. Productivity pdf's of Hungarian firms by trade and density in 1999

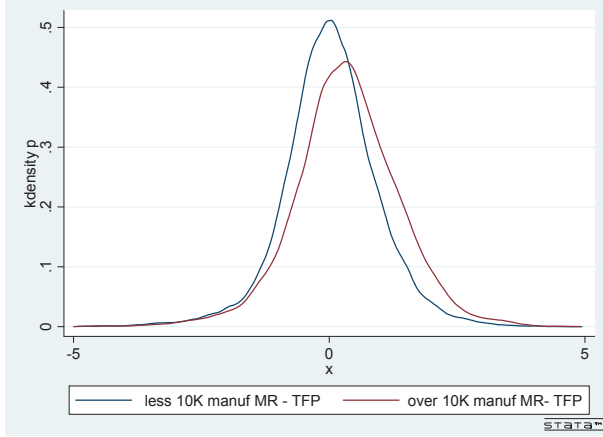

(a) by density

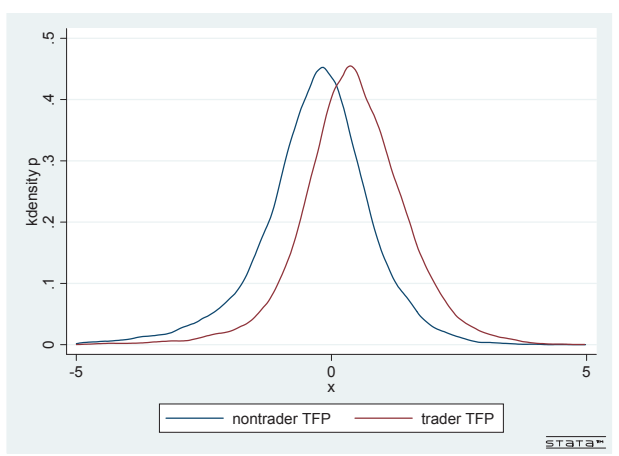

(b) by trade

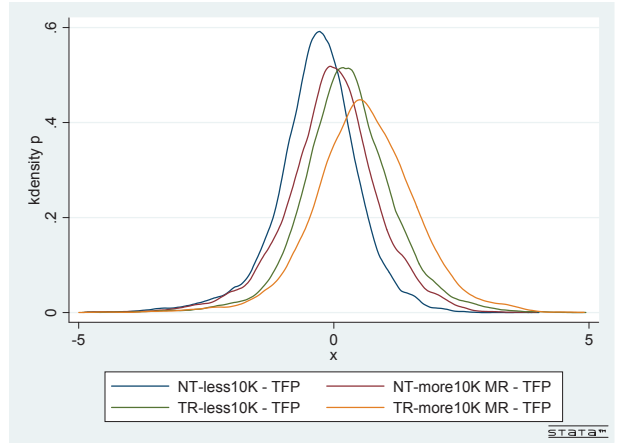

(c) by trade and density

Panel a) displays the kernel density estimates of firms' TFP (Olley \& Pakes 1996) in locations with more than 10 thousand manufacturing workers (red) and those with less (blue). Panel b) displays the kernel density estimate TFP for trading (red) and nontrading firms (blue). Panel c) displays a combination of the previous categorisation of firms.

In contrast, in panel b), when productivity distribution of traders and nontraders are compared, we find that trading firms are approximately equally more productive in all quantiles. On average Hungarian traders are 50-60 percent more productive than nontraders.

In panel c) the two previous approached are combined. Productivity distribu-

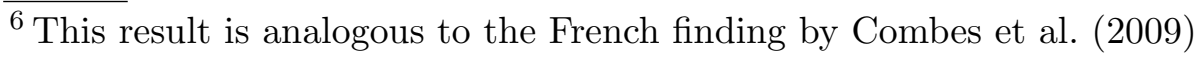


tion of firms are separately displayed by agglomeration and trade. The graph shows that distributions over agglomerated firm are in both cases of traders and nontraders the dilated version of the non-agglomerated counterpart rather than shifted. Which reinforces the notion that agglomeration on average hold more productive firms. The result also suggests that trading firms in the 10 largest Hungarian cities are the most productive ones, that is traders might be able to benefit more from an agglomerated environment.

However, while this preliminary picture gives a hint to the firm level agglomeration premium, it does not condition on firm characteristics and regional amenities. Thus, externalities at firm level will be modelled more explicitly.

\section{Estimating agglomeration premium}

Quantifying the importance of the agglomeration effects is not straightforward for at least four reasons. First, higher productivity due agglomeration economies are observationally equivalent with advantage due to first geography factors, endogenous labour quantity and quality. For example, a region that is more productive due to good climate or fertile soil will attract more labour and firms, which implies that productivity and density are simultaneous determined. Second, as agglomeration effects are estimated as a factor of productivity functions, the different channels of agglomeration are rarely identified separately: it is handled as a black-box. Third, the higher average productivity of firms in e.g. cities might be due to selectivity - low productivity firms are more likely to be forced out of the market. Thus, higher productivity of agglomerated regions could be explained by a composition problem (See e.g. Melitz \& Ottaviano (2008) and Baldwin \& Okubo (2006)). Fourth, agglomeration does not only have positive effects, but congestion effects such as pollution, higher factor prices etc. all play a role. This implies that measured agglomeration effects are the net of agglomeration benefits and congestion.

The key idea of agglomeration economies and spillovers, is that firms internalise production externalities: the presence of other economic agents enter their production function. Agglomeration economies might affect the technology of both capital and labour usage, thus we will assume they are Hicksneutral. Given these assumptions, agglomeration economies can be expressed as shifters of the productivity of the firm to a Cobb-Douglas production function of a firm, see eg. Henderson (2003) or Martin et al. (2008). In this specification an agglomeration variable enters the production function. Straight OLS estimation of such an equation in order get the casual effect running from agglomeration towards productivity has several shortcomings.

Thus, the relationship between productivity and agglomeration is estimated 
directly with $\ln \mathrm{TFP}_{i t}$ being dependent on agglomeration ${ }_{r t}$, area ant $_{r t}$ and controls. Total factor productivity $(\boldsymbol{T F P})$ is estimated by the procedure offered by Olley \& Pakes (1996). The method is suitable to control for entry and exit, within sector restructuring which is needed because the sample contain years of the transition. However, the estimation procedure has been altered to be able to better compare firms engaged in different types of trade following the modification proposed by Amiti \& Konings (2007). This allows to control for productivity gains by the real exchange rate change of the imported intermediates. We also control for the origin of the input - whether it is from a low or high-wage country - to control for the quality of the import as proposed by Altomonte \& Békés (2009). The procedure is described in the appendix in detail.

In the present paper, the agglomeration variable is calculated as the logarithm of the employment of all the manufacturing firms in the same microregion. The variable is the same for all the firms in the given region within a year as it contains the firm itself. We control for firm employment in a separate variable. ${ }^{7}$ The $\boldsymbol{a r e a}$ variable expresses the area of the microregion where the firm is located in log of square kilometers. Its inclusion is necessary to grasp the density nature of agglomeration and to express the relative proximity of firms within a microregion.

The controls include observable firm level characteristics: firmsize, a dummy variable indicating foreign ownership ${ }^{8}$ and a dummy for sectoral category.

To assess the role of trading activity in the agglomeration and productivity relationship this section uses two approaches. A trader dummy and a crossterm between the trader dummy and the agglomeration measure is included to express the targeted agglomeration premia of traders.

$$
\begin{aligned}
\ln \mathrm{TFP}_{i t} & =\alpha_{1} \text { agglomeration }_{r t}+\alpha_{2} \text { area }_{r t}+\alpha_{3} \text { trader }_{i t}+ \\
& +\alpha_{4} \text { agglomeration } \mathrm{X} \text { trader }_{i r t} \\
& +\alpha_{c t r l s} \text { controls }_{i t}+\tau_{t}+v_{r}+\nu_{i}+\text { epsilon }_{i t}
\end{aligned}
$$

Variables $v_{r}, \tau_{t}$ allow for the possibility to control for unobserved regional characteristics and for temporal effects. In fixed effect specifications, we use and $\nu_{i}$ for unobserved firm specific time-invariant heterogeneities. Note that when the regional controls include a microregion dummy, then area controls cannot be identified separately.

Using specification in equation (1) allows to control for time invariant un-

\footnotetext{
${ }^{7}$ Our results are robust in the alternative specification when excluding own employment.

${ }^{8}$ Throughout the paper, a firm is considered as foreign-owned if at least $10 \%$ of its capital is controlled by a foreign owner.
} 
observed heterogeneity at firm level, which causes biased estimation. For example, in the case of geographical regions with better first geography (better access to markets, better transportation possibilities or infrastructure), factors unobservable to the researcher that both boost productivity and attract firms create endogeneity. Firms, even in the same sector might behave differently in terms of risk taking or innovation process. In addition, more risk-taking firms are more likely to enter foreign trade, previously not served markets. This firm level idiosyncracy might affect both productivity and location choice.

The Olley-Pakes method is able to correct for the simultaneity of input choices and idiosyncratic shocks, thus it provides a feasible solution for the endogeneity of the capital and employment. Firms can foresee negative/positive technology shocks and respond by laying off/hiring workers. As most firm level panel data comes with yearly frequency, ours also, the economic shock captured by $\epsilon_{i t}$ can be correlated with the employment.

However, this approach has the disadvantage of not handling the endogeneity of the agglomeration variable to the full extent. This way, unobserved contemporaneous regional productivity shocks that might affect any other firms choice of labour input, thus influencing agglomeration variable, are not controlled for. For this reason, finding that firms in agglomerated areas are more productive is better referred to as 'agglomeration premium' rather than agglomeration effect.

Another possibility for handling the endogeneity of the inputs and agglomeration variables together would be to use the GMM method put forward by Bond (2002). Our finding is however, that GMM estimations on the Hungarian data show rather unstable result with the starting point being excessively important. ${ }^{9}$

Yet another problem needs to be solved, which arises from using aggregate indicators as regressors on firm level data. As pointed out by Moulton (1990), regressing aggregate variables on micro-level observations has the pitfall of underestimating the standard errors of the coefficient estimate. This implies that the null-hypothesis of no effect of the group level variable is rejected with higher probability.

In our regressions agglomeration variables are aggregate variables and one might run the risk of underestimating the variance of the coefficient related to them. The downward bias in the estimation of variance is caused by the unobserved characteristics the firms that are in the same vicinity have in common. This indeed might be the case for a number of reasons, e.g. they choose employment from the same pool of labour, they are affected by the same changes in local policies and depend on the same provider of utilities.

\footnotetext{
${ }^{9}$ Calculations and results are available upon request.
} 
To control for the bias in the standard errors, Moulton (1990) suggests that standard errors should be clustered according to unit of aggregation. In present case, this implies that firm level regressions use micro-regional level clustering.

\section{Results}

This section present the regression results. First, to provide a baseline picture equation (1) is estimated as pooled OLS without firm fixed effects. Second, instead of region and sector dummies, equation (1) is estimated by fixed effect specification on the separate samples of trading and nontrading firms. In principle the two approaches are the two sides of the same coin, however separating the sample also allows for the controls to take up different estimates. This section will provide modifications on the sample to account for the possible differences across trading and non-trading firms. Furthermore, specifications using fixed effect setup are investigated to confirm choice of geographical unit and that allow agglomeration channels time to take effect.

First, basic results will be presented, followed by a few subsections each suggesting a modification and discussing its result.

\subsection{Basic results}

The pooled OLS estimations provide a good basic portrayal of the relationship between agglomeration and productivity. OLS results are summarised in Table 2. The first column starts with a baseline OLS regression, where the least restrictive geographical control is used: county. Results suggest that on average firms in twice as agglomerated environments show 7.2 percent higher productivity. On top of this agglomeration premium, traders appear 2.2 percent more productive in locations where twice as many manufacturing workers are employed. The controls suggest that trading firms, larger firms and foreign owner firms are more productive. The next column uses an extra geography control named bigcity. This variable is a dummy, which takes on one if the firm is located in one of the principal cities of the 20 counties or in Vác or Budaörs, two cities near Budapest. The reason to include bigcity is to control for city amenities (infrastructure, transport hubs) that might attract firms and make them more productive and thus related to the density of the general population rather than manufacturing. We find that the dummy variable itself is positive and significant, implying that firms in the principle cities of the counties are 5 percent more productive. The control has only a minor effect on the other variables. 
Table 2

Agglomeration premia of traders, OLS and fixed effects estimations

\begin{tabular}{|c|c|c|c|c|c|}
\hline Dep. Var.: TFP & {$[1]$} & {$[2]$} & {$[3]$} & {$[4]$} & {$[5]$} \\
\hline agglomeration & $\begin{array}{l}0.0727^{* * *} \\
{[0.00399]}\end{array}$ & $\begin{array}{l}0.0574^{* * *} \\
{[0.00453]}\end{array}$ & $\begin{array}{l}0.0746^{* * *} \\
{[0.0159]}\end{array}$ & $\begin{array}{l}0.0746^{* *} \\
{[0.0376]}\end{array}$ & $\begin{array}{l}0.107^{* *} \\
{[0.0447]}\end{array}$ \\
\hline agglomeration $\mathrm{x}$ trader & $\begin{array}{l}\mathbf{0 . 0 2 3 3} * * * \\
{[0.00297}\end{array}$ & $\begin{array}{l}\mathbf{0 . 0 2 2 8} * * * \\
0.00297]\end{array}$ & $\begin{array}{l}\mathbf{0 . 0 2 3 9} * * * \\
{[0.00299]}\end{array}$ & $\begin{array}{l}\mathbf{0 . 0 2 3 9} * * * \\
{[0.00382]}\end{array}$ & $\begin{array}{l}\mathbf{0 . 0 0 5 8 3} * \\
0.00336]\end{array}$ \\
\hline trader & $\begin{array}{l}0.175^{* * *} \\
{[0.0283]}\end{array}$ & $\begin{array}{l}0.180 * * * \\
{[0.0283]}\end{array}$ & $\begin{array}{l}0.169^{* * *} \\
{[0.0284]}\end{array}$ & $\begin{array}{l}0.169^{* * *} \\
{[0.0391]}\end{array}$ & $\begin{array}{l}0.0948^{* *} \\
{[0.0389]}\end{array}$ \\
\hline firmsize & $\begin{array}{l}0.205^{* * *} \\
{[0.00296]}\end{array}$ & $\begin{array}{l}0.205^{* * *} \\
{[0.00297]}\end{array}$ & $\begin{array}{l}0.205^{* * *} \\
{[0.00298]}\end{array}$ & $\begin{array}{l}0.205^{* * *} \\
{[0.0165]}\end{array}$ & $\begin{array}{l}0.126^{* * *} \\
{[0.0221]}\end{array}$ \\
\hline foreign ownership & $\begin{array}{l}0.223 * * * \\
{[0.00674]}\end{array}$ & $\begin{array}{l}0.223^{* * *} \\
{[0.00674]}\end{array}$ & $\begin{array}{l}0.225^{* * *} \\
{[0.00675]}\end{array}$ & $\begin{array}{l}0.225^{* * *} \\
{[0.0323]}\end{array}$ & $\begin{array}{l}0.0279 * * \\
{[0.0124]}\end{array}$ \\
\hline area & $\begin{array}{l}-0.119 * * * \\
{[0.00919]}\end{array}$ & $\begin{array}{l}-0.126 * * * \\
{[0.00922]}\end{array}$ & & & \\
\hline bigcity & & $\begin{array}{l}0.0629 * * * \\
{[0.00916}\end{array}$ & $\begin{array}{l}0.132 * * * \\
{[0.0124]}\end{array}$ & $\begin{array}{l}0.132 * * * \\
{[0.0242]}\end{array}$ & \\
\hline Constant & $\begin{array}{l}-0.488^{* * *} \\
{[0.104]}\end{array}$ & $\begin{array}{l}-0.322^{* * *} \\
{[0.106]}\end{array}$ & $\begin{array}{l}-1.749 * * * \\
{[0.184]}\end{array}$ & $\begin{array}{l}-1.749^{* * *} \\
{[0.132]}\end{array}$ & $\begin{array}{l}-1.383^{* * *} \\
{[0.386]}\end{array}$ \\
\hline dummy: year & yes & yes & yes & yes & yes \\
\hline $\begin{array}{l}\text { dummy: sector } \\
\text { dummy: county }\end{array}$ & $\begin{array}{l}\text { yes } \\
\text { yes }\end{array}$ & $\begin{array}{l}\text { yes } \\
\text { yes }\end{array}$ & yes & yes & \\
\hline dummy: micro-region & & & yes & yes & \\
\hline $\begin{array}{l}\text { Moulton corr. errors } \\
\text { firm fixed effect }\end{array}$ & & & & yes & $\begin{array}{l}\text { yes } \\
\text { yes }\end{array}$ \\
\hline Observations & 100630 & 100630 & 100630 & 100630 & 100630 \\
\hline $\begin{array}{l}\text { R-squared } \\
\text { Number of id }\end{array}$ & 0.326 & 0.327 & 0.334 & 0.334 & $\begin{array}{l}0.045 \\
19150\end{array}$ \\
\hline
\end{tabular}

In the third column, instead of county level, micro-region level dummies are included. Besides refining geographical control micro-region level dummies implicitly control for the area of the geographical units over which our agglomeration variable is defined. Thus, using micro-region level controls also adjusts our agglomeration variable toward the notion of density, and captures the average distance between firms and people which translates into a measure of easiness to communicate. ${ }^{10}$ The third column results show a general agglomeration coefficient of 7.4 percent and 2.2 percent for the coefficient of the crossterm.

The fourth column, our preferred OLS specification, repeats the previous specification, but clusters standard errors according to micro-regions. As discussed previously, using aggregate measures as regressors might run the risk of underestimating standard errors. Using Moulton correction, estimated standard errors increase considerably for the coefficients of column four. For example in the case of the coefficient of agglomeration $X$ trader variable the standard error estimate increases from 0.003 to 0.004 . This highlights the importance of clustering and allows to reduce the risk of falsely rejecting the null-hypothesis of no effect.

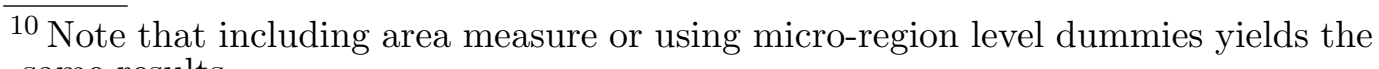
same results. 
OLS results so far suggest that trading firms are on average 2.3 percent more productive in double dense environments than non-traders. It reinforces the unconditional picture portrayed in Figure 2 of international traders being more productive in agglomerations with firm and location level conditions. OLS however fails to control for firm specific unobservables that might be correlated with the agglomeration variable.

To look at within effects, panel fixed effects estimation is employed in the fifth column of Table 2. The inclusion of firm fixed effect will not only control for the unobservable characteristics of the firm, but also that of the region that contains it. Thus it allows to control for favourable first geography characteristics that both increase productivity and attract more firms. In the case of traders it implies that we are able to control for proximity to borders, transport hubs and rivers, which both foster productivity and agglomeration of traders.

Furthermore, fixed effects specification is able to control for initial condition problems, which alleviates possible biases from spatial sorting. If more productive traders were more likely to locate in agglomeration, then not considering ex-ante higher productivity would result in attributing effects from spatial sorting to that of agglomeration. This phenomenon may be a result of increased competition of bigger cities allowing for the fittest firms to survive. Recently, Combes et al. (2009) tried to distinguish between agglomeration effects and selection of better firms for French firms. They find evidence for the former and little or no evidence for selection. Nevertheless, as fixed effects estimation identifies from within firm variation of the agglomeration variable, which is identical for both traders and non-traders by not excluding own employment, the agglomeration premia measured by within estimation can not be entirely attributed to spatial sorting.

Column five of Table 2 equation (1) uses cross-term and firm fixed effects. There are two major differences found with respect to OLS estimation. One is that the coefficient of agglomeration increased to 0.1 , the other is that we find that trading firms are only 0.5 percent more productive relative to nontrading firms in a twice as agglomerated environment. These results suggest the importance of firm level unobservables and that of spatial sorting. The decrease in the agglomeration premium of traders suggests, that more productive traders are more likely to 'self-select' to agglomeration.

Importantly, the variable of interest, the cross-term involving trader status and the agglomeration variable, is identified quite differently than in the OLS case. It is identified from those firms that switch trading status and their surrounding shows considerable change in the size of employment over time. However, we would like to narrow identification of agglomeration premium of traders to changes in the agglomeration variable and not changes in trade sta- 
tus. ${ }^{11}$ Therefore, the sample of firms is divided into three. The first subsample involves firms that never trade. The second those firms that trade occasionally, that is, it contains firms who start and discontinue to trade, or trade occasionally, while the third subsample includes firms that always trade. In this latter sample firms are allowed time to build, that is firms not trading in their first year present in the sample are considered always traders.

On each subsample equation (1) is estimated using fixed effects specification of course without the agglomeration $\times$ trader cross term. The results displayed in Table 3 imply that firms that are involved in international trade show higher productivity in agglomerated economies than nontrading firms. Also, one can observe a ranking of agglomeration premium as trade involvement over the subsample increases, both in significance and the magnitude of the coefficient estimate.

Table 3

Agglomeration premium by trading activity - separate samples FE

\begin{tabular}{llll}
\hline \hline Dep. Var.: TFP & \multicolumn{3}{c}{ firms that trade in their time present } \\
& never & occasionally & always \\
\hline \multirow{2}{*}{ agglomeration } & $\mathbf{0 . 0 6 4 2}^{*}$ & $\mathbf{0 . 1 0 9}^{*}$ & $\mathbf{0 . 1 6 3}^{* * *}$ \\
firm size & {$[0.0364]$} & {$[0.0587]$} & {$[0.0578]$} \\
& $0.0650^{* * *}$ & $0.138^{* * *}$ & $0.163^{* * *}$ \\
foreign ownership & {$[0.0165]$} & {$[0.0241]$} & {$[0.0339]$} \\
& -0.0134 & 0.0257 & $0.0749^{* * *}$ \\
Constant & {$[0.0147]$} & {$[0.0241]$} & {$[0.0178]$} \\
& $-0.889^{* *}$ & $-1.239^{* *}$ & $-1.846^{* * *}$ \\
Observations & {$[0.344]$} & {$[0.507]$} & {$[0.536]$} \\
R-squared & 27725 & 48642 & 24263 \\
Number of id & 0.023 & 0.037 & 0.082 \\
\hline *** $p<0.01, * * p<0.05,{ }^{*} p<0.1$ & 8428 & 3948 \\
Moulton corr. standard errors in parentheses & & \\
\hline
\end{tabular}

Nontrading firms on average show 6 percent higher productivity in twice as agglomerated environment, while always traders exhibit 16 percent of such premium. Occasional traders show a premium in between non-traders and always traders. Results showing that always and occasionally trading firms show higher than ten percent productivity premium in twice as dense economic environment suggests that a considerable part of the general agglomeration premia found in Hungary is due to international traders. Note that this primary role of traders in agglomeration premium detected remains true should part of the result arise from spatial sorting.

\footnotetext{
${ }^{11}$ Evidence from Békés \& Muraközy (2008) suggests considerable simultaneity between trade status change (becoming trader) and sales/productivity growth in the case of Hungarian firms. Furthermore, changes in trade status both involves a firm starting to trade and a firm discontinuing international trade activity. These firms might be affected differently by agglomeration economies.
} 
In the following subsections we take a closer and more careful look at the results of Table 3 .

\subsection{Controlling for the difference of traders}

Trading firms differ from non-traders in a number of characteristics. Table 4 illustrates the difference across trading firms in Hungarian manufacturing. It shows coefficient estimates of exporter and importer dummies regressed on the variables in the first column. We see that traders are more productive, more capital intensive and more than three times larger than non-traders. Therefore, one might argue that running regressions with the purpose of comparing these two subsets of firms runs the risk of making comparison across different parameter distribution. Hence, finding different agglomeration coefficient of traders and non-traders is affected by the fact that we do not restrict other parameters to be equal across firms. As indeed visible from Table 3 firm size and foreign ownership might have a different effect on trading and nontrading firms.

Table 4

Exporting and importing premia across manufacturers

\begin{tabular}{lcc}
\hline \hline & exporter premia & importer premia \\
\hline $\log$ of employment & 1.525 & 1.313 \\
$\log$ of value added per worker & 0.388 & 0.533 \\
$\log$ of TFP Productivity & 0.850 & 0.947 \\
$\log$ of average wage & 0.395 & 0.456 \\
$\log$ of capital per worker & 0.346 & 0.357 \\
\hline \hline
\end{tabular}

Harnessing a simple technique developed for a propensity matching approach, the overlap in covariate distributions is improved by trimming the subsample of traders and non-traders. The procedure, taken from Imbens \& Wooldridge (2008), is as follows: as a first step a logit regression is run to express the probability of being a trader while controlling for productivity, foreign ownership, firm size, general agglomeration variable and also time, region and sector fixed effects.

$$
\begin{aligned}
\operatorname{Pr}(\text { trader }=1) & =\beta_{1} \text { agglomeration }_{r t}+\beta_{2} \ln (\mathrm{TFP})_{r t} \\
& +\beta_{3} \text { controls }_{i t}+\varsigma_{r}+\chi_{t}+\psi_{i t}
\end{aligned}
$$

Obtaining the propensity score for each observation, the subsample of traders is trimmed by excluding those in the highest $20 \%$ of the score distribution of traders. Observations of non-traders being in the lowest $20 \%$ of the respective score distribution were dropped. The trimming resulted in neglecting firms whose characteristics imply that it is very unlikely that they could be in a different trade status. Though Figure 2 suggests that there is a considerable 
overlap in the productivity distribution of traders and non-traders, we would like to lessen the effect of high productivity traders on our results.

The coefficient estimates on agglomeration variable using the trimmed sample are collected in the third row of Table $5 .{ }^{12}$ To facilitate easier comparison the table also collects coefficients from regressions using plain fixed effects in its first row and replicates results of Table 3 in its second row. The second row, unlike the first, uses clustering of standard errors. We find that the Moulton correction reduces the significance of estimates in the case of the non-trader and occasionally trader sample. When comparing results from full subsamples to those obtained from using the trimmed sample two changes are observed. The coefficient in the case of never traders sinks from 6 percent to 0.6 percent and is also insignificant at any level.

The result implies that only trading firms show productivity premium in more agglomerated environment and no agglomeration premium across nontrading firms can be confirmed. It is important to note that the previous positive premia in the case of never traders were due to the strong difference of firm characteristics across the subsamples.

Table 5

Agglomeration coefficient estimates - various FE specifications

\begin{tabular}{|c|c|c|c|}
\hline \multirow{2}{*}{$\begin{array}{l}\text { Dep. Var: TFP } \\
\text { agglomeration when }\end{array}$} & \multicolumn{3}{|c|}{ firms that trade in their time present } \\
\hline & never & occasionally & always \\
\hline plain $\mathrm{FE}$ & $\begin{array}{l}0.0587^{* * *} \\
{[2.827]}\end{array}$ & $\begin{array}{l}0.109^{* * *} \\
{[5.782]}\end{array}$ & $\begin{array}{l}0.164^{* * *} \\
{[6.998]}\end{array}$ \\
\hline Moulton correction & $\begin{array}{l}0.0642^{*} \\
{[1.766]}\end{array}$ & $\begin{array}{l}0.109^{*} \\
{[1.858]}\end{array}$ & $\begin{array}{l}0.163^{* * *} \\
{[2.827]}\end{array}$ \\
\hline Trimming & $\begin{array}{l}0.00623 \\
{[0.195]}\end{array}$ & $\begin{array}{l}0.112^{*} \\
{[1.836]}\end{array}$ & $\begin{array}{l}0.170^{* * *} \\
{[2.940]}\end{array}$ \\
\hline SL-controls & $\begin{array}{l}0.0517 \\
{[1.469]}\end{array}$ & $\begin{array}{l}0.0941^{* *} \\
{[2.042]}\end{array}$ & $\begin{array}{l}0.167^{* * *} \\
{[2.822]}\end{array}$ \\
\hline Budapest omitted & $\begin{array}{l}0.023 \\
{[0.867]}\end{array}$ & $\begin{array}{l}0.0232 \\
{[0.692]}\end{array}$ & $\begin{array}{l}0.128^{* *} \\
{[2.098]}\end{array}$ \\
\hline
\end{tabular}

\footnotetext{
Standard errors in parentheses. Except for first row, results use Moulton errors.;

*** $p<0.01, * * p<0.05, * p<0.1$

Each row represents a separate regression triple. The coefficients of agglomeration variable are collected only. The first row is fixed effect without Moulton correction. The second row replicates the first, but clusters the standard errors. The third uses subsamples after most and least likely traders have been dropped. The fourth row uses spatial lag controls. The fifth uses a sample without Budapest located firms.
}

\footnotetext{
12 The detailed results for the estimations using trimmed sample and others in Table 5 are available in the Appendix in Table 12.
} 


\subsection{Adding spatial dependence controls}

When choosing micro-region level stratification as the basic unit as boundaries to external economies we neglected the possibility that agglomeration ranges further that this artificial unit. Artificial division of space causes a problem if it separates regions that are otherwise bound together economically. ${ }^{13}$ Stratification divides up the more or less continuous economic and social space. This is often the case when examining metropolises or economic regions that were previously separate cities. Also, when two regions share the same natural resource: a mountain with ores or a river. In the data, therefore, the e.g. the population of the neighbouring regions will be correlated spatially.

This problem can be remedied by point pattern analysis, using the exact geographical location of the firm or plant. Recently, Cainelli \& Lupi (2008) use this approach when estimating effects of agglomeration economies in Italy. Their results suggest that the use of geographic units, such as standard metropolitan units, administrative regions or provinces, can be misleading. Using exact distances between economic units also allows for the estimation of scope of agglomeration effects, which fade over space.

Fig. 3. Creating SL variables: Example Borsod county densities 1999

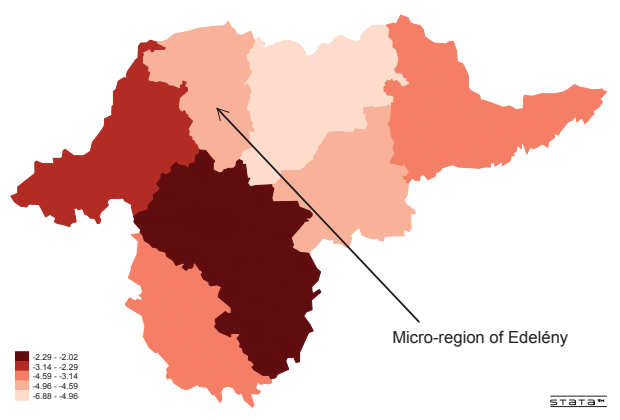

(a) agglomeration

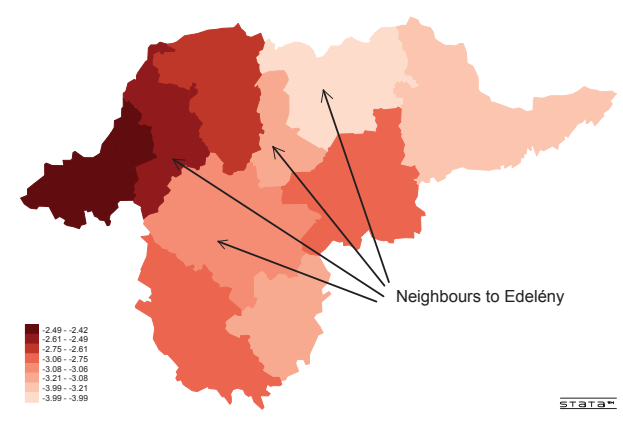

(b) SL-agglomeration

Panel a) show the spatial distribution of manufacturing employment (in logs) in Borsod county. Panel b) shows the distribution of manufacturing employment of the neighbouring microregions calculated for each region (in logs). The darker shades imply higher agglomeration.

Unfortunately, our data does not allow for such analysis, as exact address or such valuable information such as GPS coordinates, are not at our disposal. Instead, to control for agglomeration effects not bound within microregions firm level regressions including both the average characteristics of the immediate neighbouring micro regions are estimated. Note that controlling for this effect

\footnotetext{
$\overline{13}$ This problem is referred to as that of modifiable areal units (MAUP). For more extensive discussion of the problem see e.g. Briant et al. (2008), Combes \& Overman (2004)
} 
is different from the fixed effects specification as it allows for time variance in characteristics of the greater neighbourhood of the micro-region.

Figure 3 provides an illustration of the spatial autocorrelation problem and also helps the understanding of the creation of spatial lag variables (we use $S L$ prefix for spatial lag). On the left of the figure one can see the 9 microregions of Borsod county coloured according to the distribution of manufacturing employment in 1999. Borsod is in the north-east of Hungary, all borderlines to the north are the national border to Slovakia. We pick a micro-region, Edelény, as all its neighbours are within Borsod county. As pointed to on the left part of the graph, Edelény is surrounded by two very dense regions from west and south-west. Thus actually Edelény, though itself not that populated, can be considered as part of a broader agglomerated region.

Not considering spatial dependence induces problems. For example, if firms might find it profitable to locate to Edelény as they are still in the proximity of the dense and productive location of e.g. Miskolc. Then given that a considerable amount of firms like to do so, then own density and productivity will be correlated positively to both productivity and density of neighbours. Then given the assumed positive relationship between own and neighbouring micro-regions density and productivity, ignoring spatial autocorrelation will result in the overestimation of the agglomeration effect.

To control for this possible bias, spatial lag variables of employment and productivity were constructed in the following way. We took the manufacturing population and value-added measures summed over the immediate neighbouring micro-region and expressed total log of total employment in the proximity and productivity as log of total VA per total employment. Thus each micro region's immediate neighbourhood is accounted for. In the right part of Figure 3, the micro-regions of Borsod county are shaded according to the density of their neighbours. Edelény is now more heavily shaded indicating its proximity to densely populated regions.

$$
\begin{aligned}
& \text { SL-agglomeration }_{r t}=\ln \sum_{i t} \mathbf{I} \text { employment } \\
& i t
\end{aligned}
$$

where, $v a$ is firm level value added and $\mathbf{I}$ is an indicator function, which takes up value one if a firm is located in the neighbouring microregion to $\mathrm{r}$. Adding spatial dependence variables the specification to be estimated by fixed effects becomes: 


$$
\begin{aligned}
\operatorname{lnTFP} P_{i t} & =\alpha_{1} \text { agglomeration }_{r t}+\alpha_{c t r l s} \text { controls }_{i t} \\
& +\alpha_{S L A} \text { SL-agglomeration } \\
r t & +\alpha_{S L P} \text { SL-productivity }_{r t} \\
& +v_{r}+\nu_{i}+\tau_{t}+\epsilon_{i t}
\end{aligned}
$$

The results from fixed-effects regressions including spatial lag variables for neighbouring manufacturing density and productivity are collected in the fourth row of Table 5. Neighbouring productivity is found important for nontrading firms only, thus it does not change our basic inference about traders agglomeration premium.

We found that possible benefits from agglomeration can be primarily captured by choosing the microregion as a basic spatial unit. Micro-regions are not too small, such that its economy would be generally dependent on its neighbours. Results thus imply that agglomeration benefits do not expand over the 15-30 $\mathrm{km}$ radius of the micro-region.

\subsection{Controlling for Budapest}

Another reduction of the sample may be crucial given the centralised nature of Hungary. Budapest, the capital of Hungary is the most economically dense part of the country. Almost 40 percent of economic activity takes place in Budapest, which holds about twenty percent of the population and twentyfour percent of the manufacturing population. It is important to see whether the fact that Budapest can be considered an outlier in the Hungarian economic geography has a major effect on the results. Brülhart \& Mathys (2008), in their investigation of agglomeration effect in case of CEE countries, point out the important role of regions close to capitals.

To control for possible outlier driven results all firms having their headquarters located in the capital are omitted. Estimation results are displayed in the last row of Table 5 .

Two changes with respect to the whole country sample are detected. First, coefficients of never and occasionally trading firms are insignificant. This finding further confirms the agglomeration premium traders enjoy. Second, the

always trader estimate is both lower and less significant if Budapest firms are excluded from the estimation.

Results suggest that only the most intense traders enjoy agglomeration premium. However, we confirm that the agglomeration force exercised by $\mathrm{Bu}$ dapest has a great impact on Hungarian economic geography. 


\subsection{Closer to Causality}

Another important aspect of using fixed effects estimation is that it implicitly assumes changes in the local density of economic activity have immediate effect. However, benefits from agglomeration might take time to materialise. The flow of e.g. trade related information propagated by managers leaving a firm for another might take some time to take actual effect, have new contracts concluded, or new markets targeted.

To allow agglomeration not only to have immediate effect lags of agglomeration variable will be included in equation (1) when conducting fixed effects estimation on samples of never and always traders. The specification to be estimated:

$$
\begin{aligned}
\operatorname{lnTFP} P_{i t} & =\sum_{s=2}^{-1} \alpha_{1 s} \operatorname{agglomeration}_{r(t-s)} \\
& +\alpha_{c t r l s} \text { controls }_{i t}+v_{r}+\nu_{i}+\tau_{t}+\epsilon_{i t}
\end{aligned}
$$

The inclusion of lags and leads of agglomeration has another advantage, namely it might remove remaining simultaneity between contemporaneous micro-region specific shocks and the employment choice of local firms. This allows to argue more convincingly for a causal relationship between agglomeration and productivity.

Table 6 displays results using agglomeration variable leads and lags. It consists of two panels, A collects regressions for never traders, B contains regressions for always traders. The first column in each panel replicates Table 3, it uses contemporaneous agglomeration as regressor and Moulton corrected standard errors.

Columns from 2 to 4 use $t$ - 1 and $t$ - 2 lag of agglomeration variable. The results in the case of never traders reveal that there is no significant relationship between past changes in agglomeration and current productivity. However, in the case of the always trading firm all past lags used, either used individually or jointly, appear to be positive and significant. Column 4 using both lags and contemporaneous agglomeration measure suggests that it may last at least one year to have agglomeration benefits realised: the contemporaneous variable is not significant when past values are also included.

In column 5 both past and future values of agglomeration variable are included. We find that the future value of agglomeration is significant, while lagged value is not. The finding in the case of always traders is just the opposite.

Results suggest that higher productivity of traders in a more agglomerated environment can be partly attributed to a causal relationship. However, the 
Table 6

Timing Approach to Causality

\begin{tabular}{|c|c|c|c|c|c|}
\hline Dep. Var. TFP & 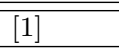 & 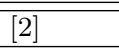 & [3] & [4] & {$[5]$} \\
\hline \multicolumn{6}{|c|}{ Panel A: never trading firms } \\
\hline agglomeration $(t+1)$ & & & & & $\begin{array}{l}0.0715^{* *} \\
{[0.0362]}\end{array}$ \\
\hline agglomeration $(\mathrm{t})$ & $\begin{array}{l}0.0642^{*} \\
{[0.0364]}\end{array}$ & & & $\begin{array}{l}0.0162 \\
{[0.0349]}\end{array}$ & \\
\hline agglomeration (t-1) & & $\begin{array}{l}0.0685 \\
{[0.0441]}\end{array}$ & & $\begin{array}{l}0.0461 \\
{[0.0368]}\end{array}$ & $\begin{array}{l}0.0468 \\
{[0.0343]}\end{array}$ \\
\hline agglomeration (t-2) & & & $\begin{array}{l}0.0364 \\
{[0.0491]}\end{array}$ & $\begin{array}{l}0.0223 \\
{[0.0417]}\end{array}$ & \\
\hline Observations & 27725 & 21522 & 16672 & 16334 & 16651 \\
\hline $\mathrm{R}$-squared & 0.023 & 0.031 & 0.029 & 0.029 & 0.028 \\
\hline Number of id & 6774 & 5299 & 4153 & 4083 & 4166 \\
\hline
\end{tabular}

Panel B: always trading firms

agglomeration $(\mathrm{t}+1)$

agglomeration $(\mathrm{t})$

agglomeration (t-1)

agglomeration (t-2)

Observations

R-squared

Number of id

*** $p<0.01, * * p<0.05, * p<0.1$, Moulton corrected standard error

Controls: firm size, foreign ownership, year effects, constant

previously detected positive relationship between agglomeration and productivity in the case of never trading firms cannot be regarded as causal. In the case of nontraders only the lead of the agglomeration variable was found significant.

\section{Possible channels of the traders' premium}

In this section traders' premium is further investigated by refining trade and agglomeration measures. First, agglomeration is separated to measure own sector concentration and agglomeration implied by employment belonging to other industries. Second, trading status will be examined separately for exporters and importers taking the intensity of trading into account. 


\subsection{Separating urbanisation and localisation}

Glaeser et al. (1992) proposed the separation of agglomeration to localisation and urbanisation effects. Localisation economies arise from spatial concentration of firms that belong to the same industry. Urbanisation economies, as proposed by Jacobs (1969), arise from the wider variety of industries and firms cross-fertilising each other. The two ideas propose different regional policies: localisation implies specialisation of a region in one or few industries or formation of clusters, while urbanisation favours access to a larger variety of inputs and promotion of industry co-location.

The within industry external economies (localisation) explicitly model the original Marshallian idea that co-located firms within industry may share common buyers and suppliers that create increasing returns, and they might harness specialised labour force. In addition, workers are more likely to change jobs within industries facilitating knowledge spillovers. Between industry externalities (urbanisation) represent the wider variety of intermediate inputs and knowledge that also generate increasing returns and proxy the fact that production takes place in a more urbanised environment.

Recently, Martin et al. (2008) have investigated the relative importance of localisation to urbanisation on French firm level data. They have found firms benefit from localisation rather than urbanisation. This study uses their formal definitions. Thus, the localisation measure at firm level is:

$$
\ln \mathrm{LOC}_{i t}=\ln \left(\text { employment }_{t k r}-\text { employment }_{i t}+1\right)
$$

where sector is $\mathrm{k}$ and location is $\mathrm{r}$. To separate the urbanisation effect, that is the spatial concentration of employment of the other sectors in a given micro-region, urbanisation is defined as:

$$
\ln \mathrm{URB}_{k t}=\ln \left(\text { employment }_{t r}-\text { employment }_{t k}+1\right)
$$

When separating localisation and urbanisation variables similar econometric problems are encountered as in the previous section. Thus, equation (1) is modified the following way:

$$
\operatorname{lnTFP} P_{i t}=\gamma_{1} \ln \mathrm{URB}_{k t}+\gamma_{2} \ln \mathrm{LOC}_{i t}+\gamma_{3} \operatorname{controls}_{i t}+v_{r}+\nu_{i}+\xi_{i t}
$$

More attention is paid to the localisation premium in this section for the following reasons. First, localisation is defined more tangibly. While, as urbanisation is a necessary complementer of localisation in describing regional economic geography, it does not provide information on the actual quality of diversity. Second, as we argued in the introduction, trade related exter- 
nal economies, such as trade specific (product or market) information, skilled labour and scale effects are more likely to work within industry.

We estimate eq. (7) with fixed effect panel specification. ${ }^{14}$ To assess the role of trading firms, again, a dual approach is used: incorporation of cross-terms of trader dummy with the agglomeration variables and separating the sample into trading and not trading firms as before. To alleviate possible biases from the contemporaneous change in trade status and the density of economic environment in cases when cross terms are included and also when subpopulation are separated, we excluded those firms that switch trade status.

Table 7

Firm level within estimations: urbanisation and localisation premia by trading

\begin{tabular}{|c|c|c|c|}
\hline $\begin{array}{l}\text { Dep. Var.: TFP Pro- } \\
\text { ductivity }\end{array}$ & all firms & $\begin{array}{l}\text { never } \\
\text { trade }\end{array}$ & $\begin{array}{l}\text { always } \\
\text { trade }\end{array}$ \\
\hline localisation & $\begin{array}{l}0.0149 \\
{[1.195]}\end{array}$ & $\begin{array}{l}0.0239^{* *} \\
{[2.161]}\end{array}$ & $\begin{array}{l}0.0328^{* *} \\
{[2.325]}\end{array}$ \\
\hline urbanisation & $\begin{array}{l}0.0239 \\
{[0.391]}\end{array}$ & $\begin{array}{l}0.0432 \\
{[1.310]}\end{array}$ & $\begin{array}{l}0.0648^{*} \\
{[1.751]}\end{array}$ \\
\hline trader & $\begin{array}{l}0.316^{* * *} \\
{[12.27]}\end{array}$ & & \\
\hline urbanisation X trader & $\begin{array}{l}0.0556 \\
{[0.649]}\end{array}$ & & \\
\hline localisation X trader & $\begin{array}{l}0.0260^{* *} \\
{[2.115]}\end{array}$ & & \\
\hline Controls* & yes & yes & yes \\
\hline dummy: year & yes & yes & yes \\
\hline Observations & 79855 & 40690 & 39165 \\
\hline R-squared & 0.048 & 0.024 & 0.081 \\
\hline Number of id & 14843 & 9167 & 5676 \\
\hline
\end{tabular}

The results are displayed in Table 7. Estimation using cross terms of localisation and urbanisation for identifying trader premium finds no significant general agglomeration coefficient, however, suggests that traders show better performance in more localised but not urbanised environments. Regression on separate samples reinforce the higher localisation premium for traders. While the localisation coefficient for non-traders is 2.4 percent, the corresponding figure for non-traders is 3.3 percent. Furthermore, separate sample regressions imply that traders show higher productivity in more urbanised environment unlike non-traders. Though the six percent urbanisation coefficient is only significant at the ten percent level, results suggest that besides the localisation, a

\footnotetext{
${ }^{14}$ When defining localisation we may find often firms that do not have any same sector neighbour within a micro region. This would imply empl $l_{t k r}-e m p l_{i t}$ is zero. Note, that we added one to both of the agglomeration variables so that we can take logarithm even in this case. This might not be as innocent as it looks: zero will appear for some firms as multiplier in their production functions due to the log-log specification. To test our possible error in inference we ran key equations excluding such firms. We found that our primary estimates of localisation are actually lower than those, independently of trade status.
} 
considerable share of previously found agglomeration premia of traders stems from urbanisation.

\subsection{Export and Import}

After the voluminous literature on the difference of exporters to other firms in many respect, recent studies suggest that import activity is equally important predictor of firm level heterogeneity. See for example Bernard et al. (2007) for exporters, Castellani et al. (2008) or Altomonte \& Békés (2009) for comparing exporters and importers). For these reasons both kinds of traders were examined. However, so far traders, either exporter or importer, were treated alike, though, exporters and importers might not draw the same benefits from agglomeration. For both exporters and importers spillovers of information about the foreign market and foreign channels are key. However, export and import related information differs. Exporters require information to market their final product: they are in need of distribution channels, they require information on consumer behaviour, and changes in regulations and standards. Importers require information for intermediate inputs: they are in need of foreign suppliers who provide input that meets their quality, price and timing needs. Import firms in an agglomerated environment, for example, are more easily targeted by foreign promoters and thus can import from abroad more easily. Furthermore, it is important that set of export and import partner countries differ in Hungary. While in both cases Germany and other European countries are foremost partners, in the case of imports Asian and Far Eastern countries' share increase gradually over time. Given the cultural distance and language barriers with these countries, to access trade related information might differ in the case of imports.

To assess the relative importance of the type of trade for agglomeration premium regressions are estimated both on separated sample and on full sample with cross terms of trade status and agglomeration included. The results are displayed in Table 8, where the first two columns are full sample within regressions for examining exporters and importers premia and the last three columns use specific subsamples of firms, never traders, always exporters and always importers. Separated sample regressions imply that both exporters and importers show higher productivity in a more agglomerated environment than non-traders. Also, importers seem to have a slightly higher premium. The close results in the case of exporters and importers are due to the large number of two-way traders in the Hungarian economy. The regressions using cross-terms confirm that importing activity plays a more important part in the higher agglomeration premium of traders. 
Table 8

Firm level within estimations: Exporters and importers separately

\begin{tabular}{|c|c|c|c|c|c|}
\hline Dep. Var: TFP & all firms & all firms & $\begin{array}{l}\text { non } \\
\text { traders }\end{array}$ & exporters & importers \\
\hline agglomeration & $\begin{array}{l}0.113^{* *} \\
{[2.522]}\end{array}$ & $\begin{array}{l}0.104^{* *} \\
{[2.346]}\end{array}$ & $\begin{array}{l}0.0483 \\
{[1.351]}\end{array}$ & $\begin{array}{l}0.104^{* *} \\
{[2.212]}\end{array}$ & $\begin{array}{l}0.125^{* *} \\
{[2.445]}\end{array}$ \\
\hline exporter & $\begin{array}{l}0.188^{* * *} \\
{[3.577]}\end{array}$ & & & & \\
\hline importer & & $\begin{array}{l}0.0778^{*} \\
{[1.747]}\end{array}$ & & & \\
\hline agglomeration $\mathrm{X}$ exporter & $\begin{array}{l}-0.0059 \\
{[-1.242]}\end{array}$ & & & & \\
\hline agglomeration $\mathrm{X}$ importer & & $\begin{array}{l}0.00844^{* *} \\
{[2.076]}\end{array}$ & & & \\
\hline Controls * & yes & yes & yes & yes & yes \\
\hline dummy: year & yes & yes & yes & yes & yes \\
\hline firm FE & yes & yes & yes & yes & yes \\
\hline Observations & 100630 & 100630 & 38460 & 47922 & 55113 \\
\hline R-squared & 0.043 & 0.045 & 0.019 & 0.07 & 0.06 \\
\hline Number of id & 19150 & 19150 & 11205 & 10788 & 12211 \\
\hline
\end{tabular}

The relative advantage of importers in agglomeration premium can be attributed to higher sensitivity to urbanisation. In Table 9 the last three columns of Table 8 are replicated with replacing the general agglomeration variable with urbanisation and localisation to disentangle possible effects. The results confirm the higher localisation premium of trading firms in case of both exporters and importers. However, the urban premium is the most significant in the case of importing firms, constituting a considerable part of traders' agglomeration premium.

Table 9

Firm level within estimations: urbanisation and localisation by exports and imports

\begin{tabular}{|c|c|c|c|}
\hline Dep. Var: TFP & $\begin{array}{l}\text { never } \\
\text { trades }\end{array}$ & exports & imports \\
\hline localisation & $\begin{array}{l}0.0223^{* *} \\
{[2.055]}\end{array}$ & $\begin{array}{l}0.0318^{* *} \\
{[2.593]}\end{array}$ & $\begin{array}{l}0.0323^{* *} \\
{[2.257]}\end{array}$ \\
\hline urbanisation & $\begin{array}{l}0.0397 \\
{[1.306}\end{array}$ & $\begin{array}{l}0.0611^{*} \\
{[1.768]}\end{array}$ & $\begin{array}{l}0.0834 * * \\
{[2.272]}\end{array}$ \\
\hline Controls * & yes & yes & yes \\
\hline Firm FE: & yes & yes & yes \\
\hline Dummy: year & yes & yes & yes \\
\hline Observations & 38460 & 47922 & 55113 \\
\hline R-squared & 0.019 & 0.071 & 0.06 \\
\hline Number of id & 11205 & 10788 & 12211 \\
\hline
\end{tabular}




\section{Concluding Remarks}

This paper investigated whether international traders are more sensitive to the density of the economic environment. A rich panel of Hungarian firms from 1992-2003 was used with detailed information on balance sheet and exportimport activity and examine the premia of agglomeration economy firms at the micro-region level (NUTS 4). It was shown that international traders are more productive in a more agglomerated environment. Pooled OLS suggest an agglomeration-trader cross-term effect of $2.5 \%$. Fixed effect regressions across trading firm imply that traders in twice as agglomerated environment are 1216 percent more productive. This result is robust when controlling for the difference in characteristics of trading and nontrading firm and outlying manufacturing density represented by the capital city, though the coefficients are smaller. Similar productivity differences across nontrading firms were found to be smaller or insignificant.

The larger part of the difference comes from the traders in more diverse environments, who are more productive, but also localisation seems to matter. Traders are on average 3.4 percent more productive in an environment that contains twice as many workers of their own sector, while the corresponding figure for non-traders is only 2.3 percent. These findings imply that international trade status is an important heterogeneity that should be taken into account when assessing agglomeration economies at firm level.

Our observation may be consistent with several phenomena. First, agglomerated environment enhances foreign trade related activities, provides better flow of information about new market possibilities, better transportation and logistics services and supplies workers with higher skills and knowledge of foreign language. Second, it is also possible that selection effects between trading and non-trading firms act differently: the least productive traders are less likely to afford congestion effects of agglomeration. Third, it is also possible trade related first geography amenities and agglomerations coincide, as in the case of a harbour city. Thus traders in other areas would suffer a more than proportionate disadvantage. We believe that after having controlled for regional characteristics the first two options are more likely. That is, agglomeration is not only beneficial for traders when it is located around a harbour or transport hub.

Hungary is a rather small open and landlocked economy, which does not necessarily make it a good playground for economic geography investigations. However, we believe that our results might serve as a possible lower bound for international traders' sensitivity to agglomeration economies and in their role of assessing its scope. 
From a policy point of view, our results are interesting for the following reasons. When evaluating cluster formation policies and promotions of agglomerated economies it is important to consider the openness of the sectors in question. Producers of nontradable goods might not benefit from these policies the same. This also implies that policies promoting agglomeration of trading firms or attracting FDI is an even more important tool of regional policy.

\section{References}

Abdel-Rahman, H. M. (1988), 'Product differentiation, monopolistic competition and city size', Regional Science and Urban Economics 18(1), 69-86.

Acharya, R. C. \& Keller, W. (2008), Estimating the productivity selection and technology spillover effects of imports, NBER Working Papers 14079, National Bureau of Economic Research, Inc.

Aitken, B., Hanson, G. H. \& Harrison, A. E. (1997), 'Spillovers, foreign investment, and export behavior', Journal of International Economics 43(12), 103-132.

Altomonte, C. \& Békés, G. (2009), 'Trade complexity and productivity', IEHAS working papers 14 .

Amiti, M. \& Konings, J. (2007), 'Trade liberalization, intermediate inputs, and productivity: Evidence from indonesia', American Economic Review 97(5), 1611-1638.

Audretsch, D. B. \& Feldman, M. P. (2004), Knowledge spillovers and the geography of innovation, in J. V. Henderson \& J. F. Thisse, eds, 'Handbook of Regional and Urban Economics'.

Baldwin, R. E. \& Okubo, T. (2006), 'Heterogeneous firms, agglomeration and economic geography: spatial selection and sorting', Journal of Economic Geography 6(3), 323-346.

Békés, G., Kleinert, J. \& Toubal, F. (2009), 'Spillovers from multinationals to heterogeneous domestic firms: Evidence from hungary', The World Economy 32(10), 1408-1433.

Békés, G. \& Muraközy (2008), 'Firm performance and switching to export', mimeo, IE-HAS.

Békés, G., Muraközy, B. \& Harasztosi, P. (2009), 'Firms and products in international trade: Data and patterns for hungary', Cefig Workig Papers no. 9 .

Bernard, A. B. \& Jensen, B. (2004), 'Why some firms export', The Review of Economics and Statistics 86(2), 561-569.

Bernard, A. B., Jensen, J. B., Redding, S. J. \& Schott, P. K. (2007), 'Firms in international trade', Journal of Economic Perspectives 21(3), 105-130.

Bernard, A. \& Jensen, B. (1999), 'Exceptional exporter performance: cause, 
effect, or both?', Journal of International Economics 47(1), 1-25.

Bleakley, H. \& Lin, J. (2007), Thick-market effects and churning in the labor market: evidence from u.s. cities, Working Papers 07-23, Federal Reserve Bank of Philadelphia.

Bond, S. (2002), Dynamic panel data models: a guide to microdata methods and practice, CeMMAP working papers CWP09/02, Centre for Microdata Methods and Practice, Institute for Fiscal Studies.

Briant, A., Combes, P.-P. \& Lafourcade, M. (2008), Dots to boxes: Do the size and shape of spatial units jeopardize economic geography estimations?, PSE Working Papers 2008-66, PSE (Ecole normale suprieure).

Brooks, E. (2003), Why don't firms export more? product quality and colombian plants, Santa Cruz Department of Economics, Working Paper Series 1036, Department of Economics, UC Santa Cruz.

Brülhart, M. \& Mathys, N. A. (2008), 'Sectoral agglomeration economies in a panel of european regions', Regional Science and Urban Economics 38(4), 348-362.

Cainelli, G. \& Lupi, C. (2008), Does spatial proximity matter? micro-evidence from italy, Economics \& Statistics Discussion Papers 08042, University of Molise.

Castellani, D., Serti, F. \& Tomasi, C. (2008), Firms in international trade: Importers and exporters heterogeneity in the italian manufacturing industry, LEM Papers Series 2008/04, Laboratory of Economics and Management (LEM), Sant'Anna School of Advanced Studies, Pisa, Italy.

Ciccone, A. (2002), 'Agglomeration effects in europe', European Economic Review 46(2), 213-227.

Ciccone, A. \& Hall, R. E. (1996), 'Productivity and the density of economic activity', American Economic Review 86(1), 54-70.

Clerides, S. K., Lach, S. \& Tybout, J. R. (1998), 'Is learning by exporting important? micro-dynamic evidence from colombia, mexico, and morocco', The Quarterly Journal of Economics 113(3), 903-947.

Combes, P. P., Duranton, G., Gobillon, L., Puga, D. \& Roux, S. (2009), The productivity advantages of large cities: Distinguishing agglomeration from firm selection, Working Papers 2009-02, Instituto Madrileno de Estudios Avanzados (IMDEA) Ciencias Sociales.

Combes, P.-P., Duranton, G., Gobillon, L. \& Roux, S. (2008), Estimating agglomeration economies with history, geology, and worker effects, CEPR Discussion Papers 6728, C.E.P.R. Discussion Papers.

Combes, P.-P. \& Overman, H. G. (2004), The spatial distribution of economic activities in the european union, in J. V. Henderson \& J. F. Thisse, eds, 'Handbook of Regional and Urban Economics', Vol. 4 of Handbook of Regional and Urban Economics, Elsevier, chapter 64, pp. 2845-2909.

Dekle, R. \& Eaton, J. (1999), 'Agglomeration and land rents: Evidence from 
the prefectures', Journal of Urban Economics 46(2), 200-214.

Foster, N. \& Stehrer, R. (2008), Sectoral productivity, density and agglomeration in the wider europe, Micro-Dyn Working paper 01/08, The Wienna Institute for International Economic Studies.

Glaeser, E. L., Kallal, H. D., Scheinkman, J. A. \& Shleifer, A. (1992), 'Growth in cities', Journal of Political Economy 100(6), 1126-52.

Glaeser, E. L. \& Mare, D. C. (2001), 'Cities and skills', Journal of Labor Economics 19(2), 316-42.

Halpern, L., Koren, M. \& Szeidl, A. (2009), Imported inputs and productivity, Cefig working papers, CeFIG Working Papers no. 8.

Hanson, G. H. (2000), Scale economies and the geographic concentration of industry, Nber working papers, National Bureau of Economic Research, Inc.

Henderson, J. V. (2003), 'Marshall's scale economies', Journal of Urban Economics 53(1), 1-28.

Imbens, G. W. \& Wooldridge, J. M. (2008), Recent developments in the econometrics of program evaluation, IZA Discussion Papers 3640, Institute for the Study of Labor (IZA).

Imbriani, C., Morone, P. \& Testa, G. (2008), Exporting quality: is it the right strategy for the italian manufacturing sector?, MPRA Paper 13327, University Library of Munich, Germany.

Jacobs, J. (1969), The Economy of Cities, Random House, New York.

Jaffe, A. B., Trajtenberg, M. \& Henderson, R. (1993), 'Geographic localization of knowledge spillovers as evidenced by patent citations', The Quarterly Journal of Economics 108(3), 577-98.

Kneller, R. \& Pisu, M. (2007), 'Industrial linkages and export spillovers from fdi', The World Economy 30(1), 105-134.

Koenig, P. (2005), 'International trade and internal geography: Theory and firm-level evidence', Phd Dissertation, Univ. Paris I, Sorbonne.

Krugman, P. (1991), 'Increasing returns and economic geography', Journal of Political Economy 99(3), 483-99.

Lovely, M. E., Rosenthal, S. S. \& Sharma, S. (2005), 'Information, agglomeration, and the headquarters of u.s. exporters', Regional Science and Urban Economics 35(2), 167-191.

Lucas, R. J. (1988), 'On the mechanics of economic development', Journal of Monetary Economics 22(1), 3-42.

Marshall, A. (1920), Principal of Economics: An introductory volume, 8th edn, Procupine Press, Philadelphia. Reprinted in 1990.

Martin, P., Mayer, T. \& Mayneris, F. (2008), Spatial concentration and firmlevel productivity in france, CEPR Discussion Papers 6858, C.E.P.R. Discussion Papers.

Mayer, T. \& Ottaviano, G. (2008), 'The happy few: The internationalisation of european firms', Intereconomics: Review of European Economic Policy 
43(3), 135-148.

Melitz, M. J. \& Ottaviano, G. I. P. (2008), 'Market size, trade, and productivity', Review of Economic Studies 75(1), 295-316.

Moulton, B. R. (1990), 'An illustration of a pitfall in estimating the effects of aggregate variables on micro unit', The Review of Economics and Statistics 72(2), 334-38.

Olley, G. S. \& Pakes, A. (1996), 'The dynamics of productivity in the telecommunications equipment industry', Econometrica 64(6), 1263-97.

Ottaviano, G., Tabuchi, T. \& Thisse, J.-F. (2002), 'Agglomeration and trade revisited', International Economic Review 43(2), 409-436.

Pakes, A. (1991), Dynamic structural models: Problems and prospects. mixed continuous discrete controls and market interactions, Cowles Foundation Discussion Papers 984, Cowles Foundation, Yale University.

Rosenthal, S. S. \& Strange, W. C. (2004), Evidence on the nature and sources of agglomeration economies, in J. V. Henderson \& J. F. Thisse, eds, 'Handbook of Regional and Urban Economics'.

Soon, L., K. D. \& Fraser, C. (2006), Making tacit knowledge explicit: Designing an export trading knowledge portal, in A. Ruth, ed., 'Quality and Impact of Qualitative Research. 3rd annual QualIT Conference, Brisbane'.

Strøjer Madsen, E., Smith, V. \& Dilling-Hansen, M. (2003), Industrial clusters, firm location and productivity: Some empirical evidence for danish firms, Working Papers 03-26, University of Aarhus, Aarhus School of Business, Department of Economics. 


\section{Technical Appendix}

This appendix section describes the productivity estimation approached we used. To address econometric problems arising from selection, input endogeneity and that of trade status we used a modified version of the estimation method proposed by Olley \& Pakes (1996), (OP). We start the following CobbDouglas production function using indices $i$ for the firm and $t$ for time.

$$
y_{i t}=\beta_{0}+\beta_{k} k_{i t}+\beta_{l} l_{i t}+\beta_{m} m_{i t}+\omega_{i t}+\epsilon_{i t}
$$

where $y_{i t}, k_{i t}, l_{i t}, m_{i t}$ denote the natural logarithm of output, capital, labour and inputs. Productivity is denoted by $\omega_{i t}$ and $\epsilon_{i t}$ stands for the measurement error in output. In our analysis output is captured by real value added, capital is by the deflated value of tangible fixed assets and labour by annual employment. Productivity is assumed to follow a first order Markov process:

$$
\omega_{i, t+1}=E\left[\omega_{i, t+1} \mid \omega_{i, t}\right]+\eta_{i, t+1}
$$

with $\eta_{i t}$ being an exogenous shock process.

Estimating equation [8] by OLS entails several problems. First, due to the annual periodicity of the data, it is safe to assume, that firms get a fair perception of productivity process for the period at beginning of the year and are able to change their decision on input choices accordingly. That is, $k_{i t}$, $l_{i t}$ are correlated with $\omega_{i t}$, which makes estimation biased and inconsistent. Secondly, every year firms whose productivity falls below a certain threshold will be forced to shut down. This implies, that next year productivity distribution will be of a selected sample of the surviving firms. Ignoring the selection problems will again bias the estimation of the input coefficients. Thirdly, as internalisation plays primary role in our analysis we need to consider the possibility that investment and exit behaviour of the firm is correlated with its export and import status. Furthermore, trading firms, especially importers face different input prices. Exchange rate changes over the examined period might induce a measurement error in the prices used in the estimation. This problem raised by e.g. Amiti \& Konings (2007). To account for these issues we used two modifications to the standard OP procedure. On one hand, when calculating value added, imported input values account for the changes in real exchange rate. On the other hand the $\mathrm{OP}$ procedure investment processes involves firms export and import status.

The OP relies on the existence of a monotonic relationship between investment $i_{i t}$, capital and productivity, see Pakes (1991). Therefore this relationship can be inverted to express productivity of the firm. 


$$
\omega_{i, t}=g\left(k_{i t}, i_{i t}\right)
$$

For aforementioned reasons we also include trade variables in the investment decision. $\mathrm{X}$ is export status dummies, taking up one when the firms show activity of trade. The dummy for import activity was split to indicate trade from low and from high wage countries, $M L_{i t}$ and $M H_{i t}$ respectively. Substituting for the unobserved productivity term:

$$
y_{i t}=\beta_{l} l_{i t}+\beta_{m} m_{i t}+\phi_{i t}\left(i_{i t}, k_{i t}, X_{i t}, M L_{i t}, M H_{i t}\right)+\epsilon_{i t}
$$

This regression gives consistent estimates of $\beta_{l}$ and $\beta_{m}$. Since the functional form of $\phi(\cdot)$ is unknown, we use a linear model that includes full interaction term polynomials of the arguments. The estimation provides $\hat{\phi}$.

The second stage of the estimation, that control for the selection bias caused by low productivity firms exiting the sample gives the estimates of the remaining coefficients. The probability that a firm survives to $\mathrm{t}\left(s_{t}\right)$ can be expressed as being above a certain productivity threshold $\underline{\omega}_{t}$. The survival probability $\left(P_{t}\right)$ can be estimated by probit regression as a polynomial function of capital and investment and trade status crossterms.

$$
\operatorname{Pr}\left(s_{t}=1 \mid \underline{\omega}_{t}\left(k_{t}\right)\right)=\varphi\left(i_{t-1}, k_{t-1}, X_{t-1}, M L_{t-1}, M H_{t-1}\right)
$$

Rearranging 8 and taking expectations given that the firm survived, we have:

$$
E\left(y_{i t}-\beta_{l} l_{i t}-\beta_{m} m_{i t} \mid k_{i t}, s_{t}=1\right)=\beta_{0}+\beta_{k} k_{i t}+E\left(\omega_{i t} \mid \omega_{i, t-1}, s_{t}=1\right)
$$

Using the Markov property of productivity, and the notion that once survival and past productivity is realised $k_{i t}$ is known.

$$
\begin{aligned}
y_{i t}-\beta_{l} l_{i t}-\beta_{m} m_{i t} & =\beta_{k} k_{i t}+E\left(\omega_{i t} \mid \omega_{i, t-1}, s_{t}=1\right)+ \\
& +\omega_{i, t+1}-E\left[\omega_{i, t+1} \mid \omega_{i, t}\right]-\eta_{i, t+1} \\
& =\beta_{k} k_{i t}+E\left(\omega_{i t} \mid \omega_{i, t-1}, s_{t}=1\right)+\xi_{i t}-\eta_{i, t+1}
\end{aligned}
$$

where $\xi_{i t}$ is the surprise efficiency for surviving firms, which does not effect last period exit or investment choice. The remaining unknown $E\left(\omega_{i t} \mid \omega_{i, t-1}, s_{t}=1\right)$ is a function of past unobserved productivity and surviving probability. Olley \& Pakes (1996) suggest to proxy these variables with the estimated survival probability and the lagged value of investment function estimated in the first stage:

$$
y_{i t}-\beta_{l} l_{i t}-\beta_{m} m_{i t}=\beta_{k} k_{i t}+\theta\left(P_{t-1}, \phi_{i, t-1}-\beta_{k} k_{i t}\right)+\nu_{i t}+\epsilon_{i, t-1}
$$

Using the estimated values of $P_{t-1}, \phi_{i, t-1}$ and of $\beta_{l}, \beta_{m}$ from previous stages, 
expressing $\theta$ as polynomial of its components, one can estimate remaining coefficients running equation 15 . Using all estimated coefficients the log of TFP, as residual of the production function can be calculated.

$$
t f p_{i t}=\hat{\beta}_{0}+\hat{\beta}_{k} k_{i t}+\hat{\beta}_{k} k_{i t}+\hat{\beta}_{m} m_{i t}
$$




\section{Appendix of Tables and Graphs}

Fig. 4. Spatial distribution of Manufacturing Productivity 1999

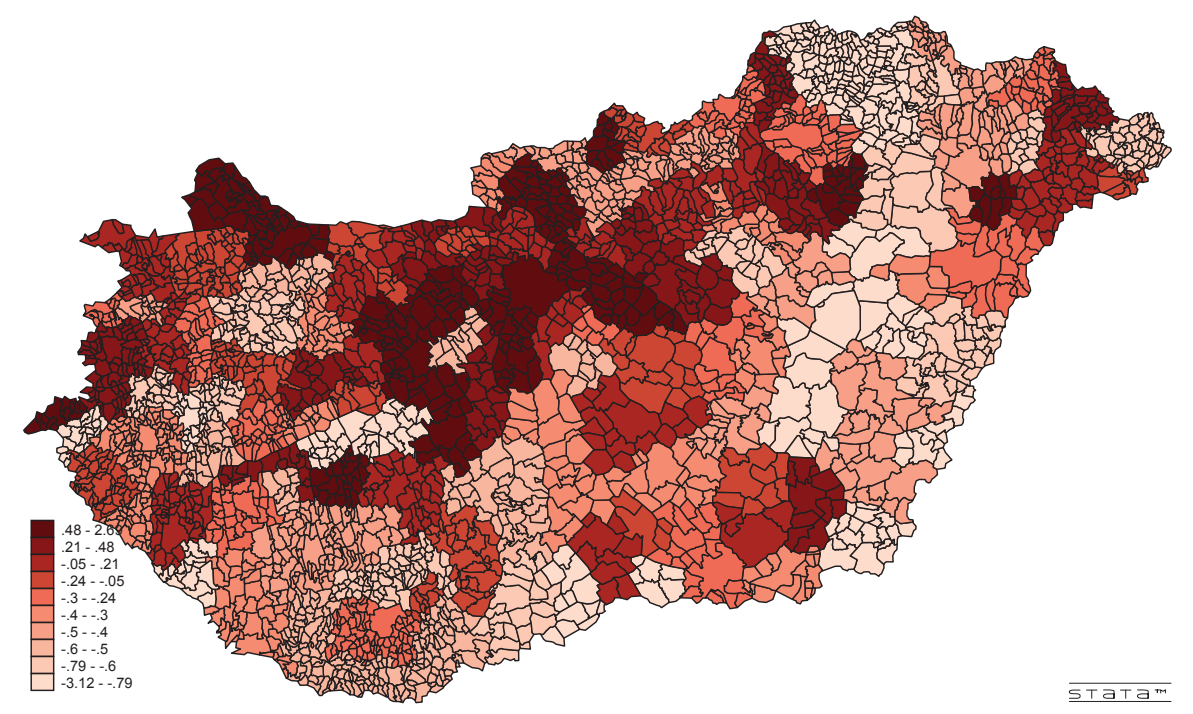

Fig. 5. Spatial distribution of Manufacturing Density 1999

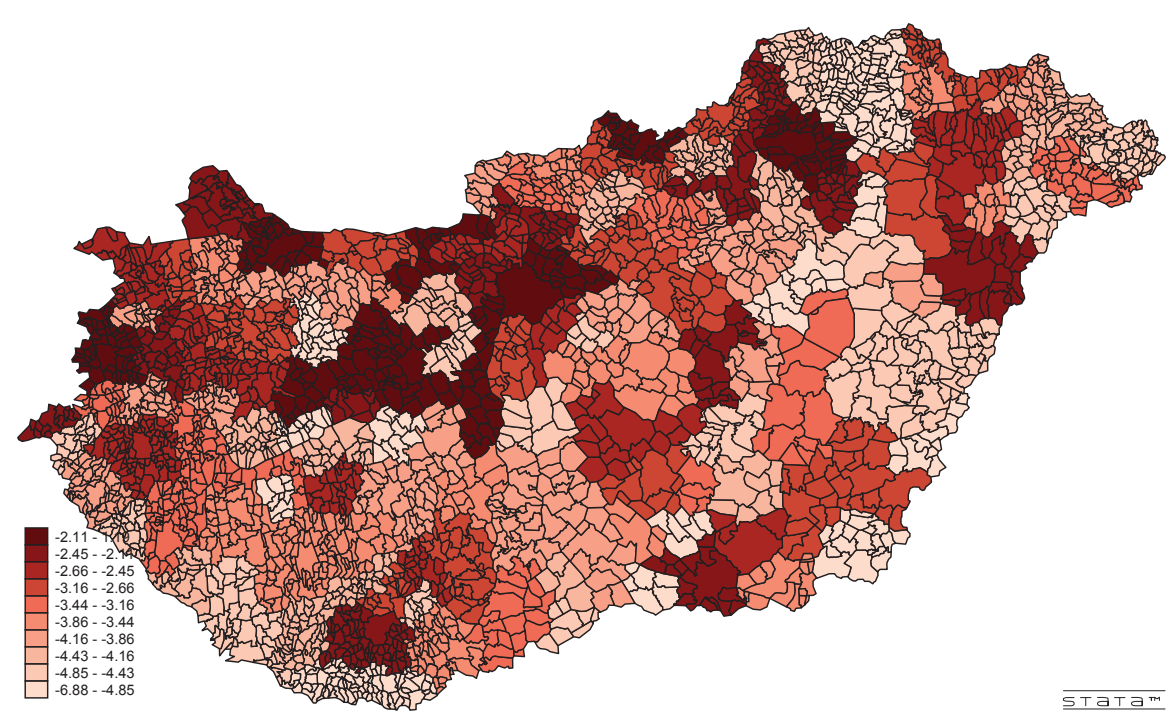


Table 10

Basic Geographical Description

\begin{tabular}{lrrr}
\hline \hline County & Area $\left(\mathrm{km}^{2}\right)$ & $\begin{array}{r}\text { Population } \\
(\text { mean })\end{array}$ & Num.Districts \\
\hline Budapest & 525 & 1865321 & 1 \\
Baranya & 4430 & 406600 & 8 \\
Bács-kiskun & 8445 & 540004 & 10 \\
Békés & 5631 & 398598 & 6 \\
Borsod-Abaúj-Zemplén & 7247 & 741667 & 11 \\
Csongrád & 4263 & 426202 & 7 \\
Fejér & 4359 & 424703 & 7 \\
Györ-Moson-Sopron & 4208 & 432209 & 6 \\
Hajdú-Bihar & 6211 & 547807 & 7 \\
Heves & 3637 & 326300 & 6 \\
Komárom-Esztergom & 2265 & 313982 & 7 \\
Nógrád & 2544 & 220236 & 6 \\
Pest & 6393 & 1021686 & 14 \\
Somogy & 6036 & 335456 & 9 \\
Szabolcs-Szatmár-Bereg & 5937 & 574007 & 10 \\
Jász-Nagykun-Szolnok & 5582 & 416675 & 6 \\
Tolna & 3701 & 247895 & 5 \\
Vas & 3336 & 269367 & 9 \\
Veszprém & 4493 & 371070 & 9 \\
Zala & 3784 & 298131 & 6 \\
\hline & 4651 & 508896 & 7.5 \\
\hline \hline
\end{tabular}


Table 11

Micro-region characteristics

\begin{tabular}{|c|c|c|c|c|c|c|c|c|c|}
\hline MR & $\begin{array}{l}\text { avg. } \\
\text { Pop. }\end{array}$ & $\begin{array}{r}\text { avg. } \\
\text { manuf. } \\
\text { empl. }\end{array}$ & $\begin{array}{l}\text { avg. } \\
\text { N. of } \\
\text { firms }\end{array}$ & $\begin{array}{l}\text { area } \\
\text { (ha) }\end{array}$ & MR & $\begin{array}{l}\text { avg. } \\
\text { Pop. }\end{array}$ & $\begin{array}{r}\text { avg. } \\
\text { manuf. } \\
\text { empl. }\end{array}$ & $\begin{array}{l}\text { avg. } \\
\text { N. } \\
\text { of } \\
\text { firms }\end{array}$ & $\begin{array}{l}\text { area } \\
\text { (ha) }\end{array}$ \\
\hline Ajka & 60584 & 5651 & 72 & 74344 & Mezőkovácsháza & 48823 & 471 & 11 & 93355 \\
\hline Aszód & 36011 & 1035 & 41 & 30907 & Mezőkövesd & 47021 & 1086 & 30 & 77048 \\
\hline Baja & 78086 & 3466 & 107 & 118996 & Miskolc & 277565 & 14984 & 378 & 101757 \\
\hline Baktalórántháza & 23302 & 429 & 10 & 31800 & Mohácsi & 54322 & 2452 & 67 & 87944 \\
\hline Balassagyarmat & 43322 & 1717 & 45 & 53188 & Monor & 36650 & 303 & 28 & 23573 \\
\hline Balatonalmádi & 24719 & 3441 & 40 & 28649 & Mosonmagyaróvár & 71521 & 7333 & 128 & 93070 \\
\hline Balatonfüred & 21769 & 142 & 22 & 31847 & Mátészalka & 66579 & 1826 & 30 & 62474 \\
\hline Balmazújváros & 30549 & 645 & 11 & 73122 & Mór & 28165 & 4184 & 34 & 29456 \\
\hline Barcs & 26846 & 790 & 28 & 69647 & Mórahalom & 16839 & 40 & 6 & 41172 \\
\hline Berettyóújfalu & 66177 & 1811 & 41 & 137231 & Nagyatád & 28823 & 545 & 21 & 64707 \\
\hline Bicske & 34701 & 440 & 24 & 61872 & Nagykanizsa & 83951 & 3562 & 71 & 89254 \\
\hline Bonyhád & 30873 & 2781 & 37 & 37756 & Nagykálló & 32027 & 693 & 21 & 37741 \\
\hline Budapest & 1905661 & 188280 & 6899 & 52516 & Nagykáta & 72674 & 1198 & 43 & 77945 \\
\hline Budaörs & 110334 & 5073 & 340 & 20791 & Nyirbátor & 44369 & 577 & 24 & 69595 \\
\hline Bácsalmás & 18426 & 424 & 8 & 38109 & Nyiregyháza & 214818 & 9329 & 309 & 143814 \\
\hline Bátonyterenye & 27803 & 1308 & 32 & 27839 & Orosháza & 66040 & 3810 & 72 & 84858 \\
\hline Békéscsaba & 167954 & 8326 & 185 & 141581 & Oroszlány & 28683 & 1382 & 21 & 19936 \\
\hline Cegléd & 116920 & 3291 & 123 & 123403 & Paks & 48957 & 2072 & 44 & 75687 \\
\hline Celldömölk & 27297 & 3064 & 29 & 47420 & Piliscsaba & 75344 & 3550 & 222 & 37991 \\
\hline Csenger & 14176 & 573 & 9 & 24658 & Polgár & 14678 & 91 & 8 & 38387 \\
\hline Csepreg & 11407 & 318 & 14 & 19683 & Pápa & 64053 & 3776 & 73 & 100140 \\
\hline Csongrád & 25403 & 1557 & 20 & 33924 & Pásztó & 34134 & 597 & 34 & 55165 \\
\hline Csorna & 36514 & 1266 & 26 & 63276 & Pécsi & 206231 & 10890 & 397 & 94848 \\
\hline Csurgó & 19200 & 663 & 12 & 49619 & Pécsváradi & 11214 & 173 & 13 & 20014 \\
\hline Dabas & 39645 & 1152 & 63 & 49870 & Pétervására & 22949 & 375 & 13 & 42626 \\
\hline Debrecen & 290521 & 16847 & 383 & 153196 & Püspökladány & 52653 & 890 & 28 & 95352 \\
\hline Dombóvár & 35222 & 1325 & 41 & 50947 & Ráckeve & 107418 & 3754 & 260 & 62846 \\
\hline Dorog & 39919 & 1727 & 52 & 23270 & Rétság & 25078 & 1057 & 30 & 43502 \\
\hline Dunakeszi & 57091 & 2989 & 124 & 10308 & Salgótarján & 70035 & 6871 & 95 & 46980 \\
\hline Dunaújváros & 109920 & 11741 & 127 & 75067 & Sarkad & 26739 & 238 & 6 & 54661 \\
\hline Edelény & 35780 & 645 & 20 & 73935 & Sellye & 13424 & 142 & 5 & 41056 \\
\hline Eger & 96729 & 6551 & 150 & 74104 & Siklósi & 35855 & 613 & 27 & 62410 \\
\hline Encs & 35031 & 557 & 9 & 79612 & Siófok & 47056 & 637 & 46 & 62783 \\
\hline Enying & 24674 & 81 & 5 & 48090 & Sopron & 90744 & 6743 & 153 & 85737 \\
\hline Esztergom & 54478 & 7748 & 129 & 30486 & Szarvas & 42455 & 2688 & 42 & 73982 \\
\hline Fehérgyarmat & 38858 & 711 & 15 & 69641 & Szeged & 206262 & 10392 & 355 & 87598 \\
\hline Fonyód & 28097 & 1006 & 36 & 42887 & Szeghalom & 48271 & 958 & 20 & 114670 \\
\hline Füzesabony & 37093 & 848 & 22 & 66939 & Szekszárd & 89506 & 4149 & 114 & 103027 \\
\hline Gyál & 89955 & 2392 & 126 & 43284 & Szentendre & 63226 & 2819 & 204 & 34262 \\
\hline Győr & 170880 & 19304 & 336 & 72735 & Szentes & 46490 & 1618 & 36 & 81388 \\
\hline Gyöngyös & 76900 & 1012 & 18 & 73344 & Szentgotthárd & 15363 & 2163 & 26 & 23344 \\
\hline Gárdony & 32318 & 417 & 28 & 37890 & Szerencs & 63546 & 724 & 42 & 83676 \\
\hline Gödöllő & 103616 & 7494 & 186 & 44961 & Szigetvári & 28263 & 722 & 20 & 66887 \\
\hline Hajdúböszörmény & 59222 & 3677 & 64 & 73106 & Szikszó & 19802 & 47 & 3 & 31165 \\
\hline Hajdúszoboszló & 33295 & 730 & 33 & 50674 & Szob & 12384 & 429 & 16 & 31486 \\
\hline Hatvan & 56403 & 2697 & 91 & 36955 & Szolnok & 122525 & 9847 & 204 & 87752 \\
\hline Heves & 36992 & 1552 & 47 & 69779 & Szombathely & 115111 & 13386 & 210 & 64636 \\
\hline Hódmezővásárhely & 61060 & 5060 & 111 & 70782 & Szécsény & 20380 & 1492 & 23 & 27741 \\
\hline Jánoshalma & 17896 & 622 & 14 & 39914 & Székesfehérvár & 163377 & 17441 & 313 & 118133 \\
\hline Jászberény & 88411 & 6757 & 96 & 116146 & Sárbogárd & 30148 & 1042 & 8 & 65368 \\
\hline Kalocsa & 56803 & 1725 & 63 & 102903 & Sárospatak & 28370 & 1018 & 31 & 47760 \\
\hline Kaposvár & 123577 & 4553 & 126 & 157474 & Sárvár & 37563 & 3676 & 28 & 59029 \\
\hline Kapuvár & 25833 & 1756 & 28 & 38271 & Sásdi & 16177 & 449 & 22 & 38387 \\
\hline Karcag & 77238 & 3801 & 90 & 138360 & Sátoraljaújhely & 44391 & 3288 & 32 & 71158 \\
\hline Kazincbarcika & 66189 & 5047 & 44 & 50375 & Sümeg & 16524 & 510 & 15 & 30640 \\
\hline Kecskemét & 163329 & 9347 & 339 & 148318 & Tab & 17201 & 1650 & 14 & 47962 \\
\hline Keszthely & 46359 & 2196 & 40 & 50456 & Tamási & 43323 & 1966 & 40 & 102613 \\
\hline Kisbér & 21270 & 650 & 28 & 51075 & Tapolca & 38107 & 829 & 34 & 54021 \\
\hline Kiskunfélegyháza & 52416 & 3716 & 63 & 81072 & Tata & 38881 & 1610 & 94 & 30678 \\
\hline Kiskunhalas & 46876 & 1398 & 58 & 82635 & Tatabánya & 88972 & 3905 & 174 & 33166 \\
\hline Kiskunmajsa & 16932 & 892 & 21 & 39192 & Tiszafüred & 41934 & 799 & 17 & 84661 \\
\hline Kiskőrös & 58125 & 1548 & 69 & 113033 & Tiszavasvári & 28534 & 2786 & 11 & 38167 \\
\hline Kistelek & 19498 & 75 & 10 & 41020 & Tiszaújváros & 46750 & 6196 & 54 & 53274 \\
\hline Kisvárda & 69564 & 1267 & 23 & 52835 & Tét & 30572 & 758 & 18 & 55778 \\
\hline Komló & 42590 & 1766 & 60 & 31462 & Törökszentmiklós & 47022 & 1093 & 34 & 60332 \\
\hline Komárom & 41181 & 1448 & 58 & 37898 & Vasvár & 15938 & 593 & 10 & 37414 \\
\hline Kunszentmiklós & 30676 & 873 & 24 & 80281 & Veszprém & 86130 & 7820 & 181 & 65670 \\
\hline Kunszentmárton & 40238 & 855 & 23 & 70923 & Vác & 71056 & 5074 & 126 & 47720 \\
\hline Kőszeg & 17812 & 2358 & 19 & 18505 & Várpalota & 37459 & 3869 & 34 & 27045 \\
\hline Körmend & 22502 & 950 & 17 & 33091 & Vásárosnamény & 37626 & 699 & 17 & 62940 \\
\hline Lengyeltóti & 12193 & 141 & 8 & 27095 & Zalaegerszeg & 105617 & 8273 & 166 & 99270 \\
\hline Lenti & 24386 & 1242 & 33 & 66311 & Zalaszentgrót & 18967 & 1077 & 26 & 32712 \\
\hline Letenye & 19602 & 358 & 16 & 40409 & Zirc & 26455 & 410 & 18 & 48904 \\
\hline Makó & 51303 & 1648 & 33 & 70385 & Ózd & 76815 & 3418 & 60 & 54957 \\
\hline Marcali & 32942 & 1453 & 27 & 81409 & Öriszentpéter & 7577 & 670 & 11 & 30523 \\
\hline
\end{tabular}




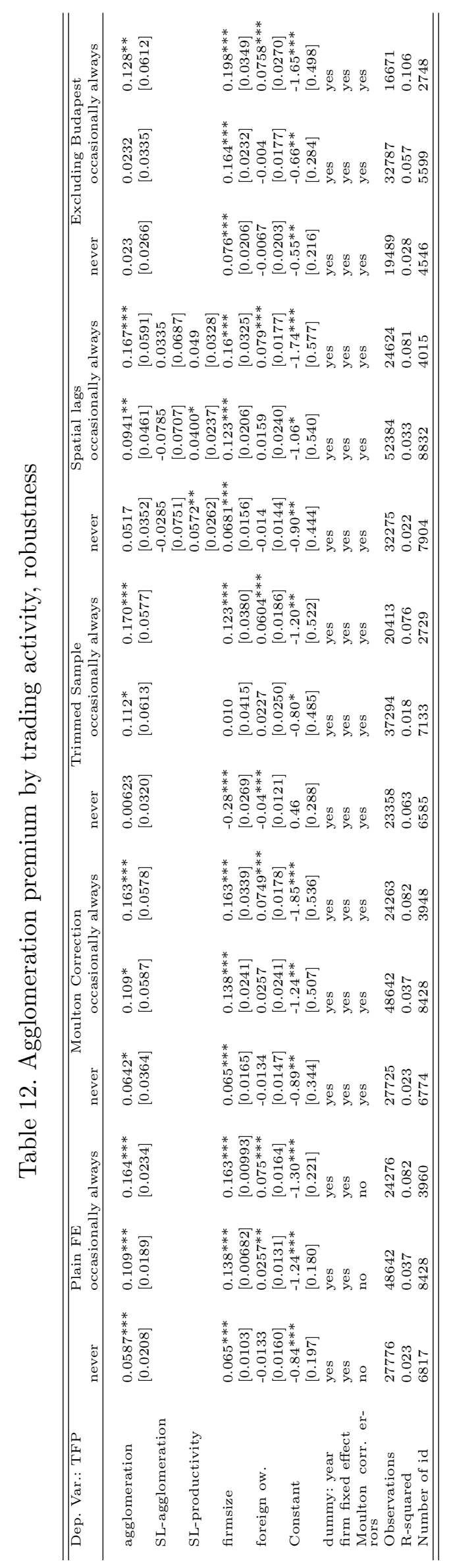


Discussion Papers published in 2009

Judit KARSAI: The End of the Golden Age - The Developments of the Venture Capital and Private Equity Industry in Central and Eastern Europe. MT-DP. 2009/1

András SIMONOVITS: When and How to Subsidize Tax-Favored Retirement Accounts? MT-DP.2009/2

Mária CSANÁDI: The "Chinese Style Reforms" and the Hungarian "Goulash Communism". MT-DP. 2009/3

Mária CSANÁDI: The Metamorphosis of the Communist Party: from Entity to System and from System towards an Entity. MT-DP. 2009/4

Mária CSANÁDI - Hairong LAI - Ferenc GYURIS: Global Crisis and its Implications on the Political Transformation in China. MT-DP. 2009/5

DARVAS Zsolt - SZAPÁRY György: Árszínvonal-konvergencia az új EU tagországokban: egy panel-regressziós modell eredményei. MT-DP. 2009/6

KÜRTI Andrea - KOZAK Anita - SERES Antal - SZABÓ Márton: Mezőgazdasági kisárutermelők nagy kereskedelmi láncooknak történő beszállítása a nagyvevői igények alapján a zöldség-gyümölcs ágazatban. MT-DP.2009/7

András SIMONOVITS: Hungarian Pension System and its Reform. MTDP.2009/8

Balázs MURAKÖZY - Gábor BÉKÉS: Temporary Trade. MT-DP. 2009/9

Alan AHEARNE - Herbert BRÜCKER - Zsolt DARVAS - Jakob von WEIZSÄCKER: Cyclical Dimensions of Labour Mobility after EU Enlargement. MT-DP. 2009/10

Max GILLMAN - Michal KEJAK: Inflation, Investment and Growth: a Money and Banking Approach. MT-DP. 2009/11

Max GILLMAN - Mark N. HARRIS: The Effect of Inflation on Growth: Evidence from a Panel of Transition Countries. MT-DP. 2009/12

Zsolt DARVAS: Monetary Transmission in Three Central European Economies: Evidence from Time-Varying Coefficient Vector Autoregressions. MT-DP. 2009/13

Carlo ALTOMONTE - Gábor BÉKÉS: Trade Complexity and Productivity. MT-DP. 2009/14

András SIMONOVITS: A Simple Model of Tax-Favored Retirement Accounts. MT-DP. 2009/15

Ádám SZENTPÉTERI - Álmos TELEGDY: Political Selection of Firms into Privatization Programs. Evidence from Romanian Comprehensive Data. MT-DP. 2009/16

András SIMONOVITS: Pension Reforms in an Aging Society: A Fully Displayed Cohort Model. MT-DP. 2009/17

VALENTINY Pál - KISS Károly Miklós: A nélkülözhetetlen eszközök értelmezése és a postai szolgáltatások. MT-DP. 2009/18 
Gábor BÉKÉS - Péter HARASZTOSI - Balázs MURAKÖZY: Firms and Products in International Trade: Data and Patterns for Hungary. MT-DP. 2009/19

KARSAI Judit: Áldás vagy átok? A magántőke-befektetések hatása a gazdaságra. MT-DP. 2009/20

László HALPERN-Balázs MURAKÖZY: Innovation, Productivity and Exports: the Case of Hungary. MT-DP. 2009/21

Zsuzsa KAPITÁNY: Non-employment, Ill-being and Subjective Well-being. MT-DP. 2009/22

Szilárd BENK-Max GILLMAN-Michal KEJAK: A Banking Explanation of the US Velocity of Money: 1919-2004. MT-DP. 2009/23

Zsolt DARVAS: The Impact of the Crisis on Budget Policy in Central and Eastern Europe. MT-DP. 2009/24

NEMES Gusztáv: Gondolatok a vidékfejlesztési programok értékeléséról: Társadalmi tanulás a LEADER programban. MT-DP. 2009/25

Ádám SZENTPÉTERI - Álmos TELEGDY: Political Objectives and Privatization Decisions. Selection of Firms into Privatization or Long-Term State Ownership in Romania. MT-DP. 2009/26

András SIMONOVITS: Underreported Earnings and Age-Specific Income Redistribution in Post-Socialist Economies. MT-DP. 2009/27 